
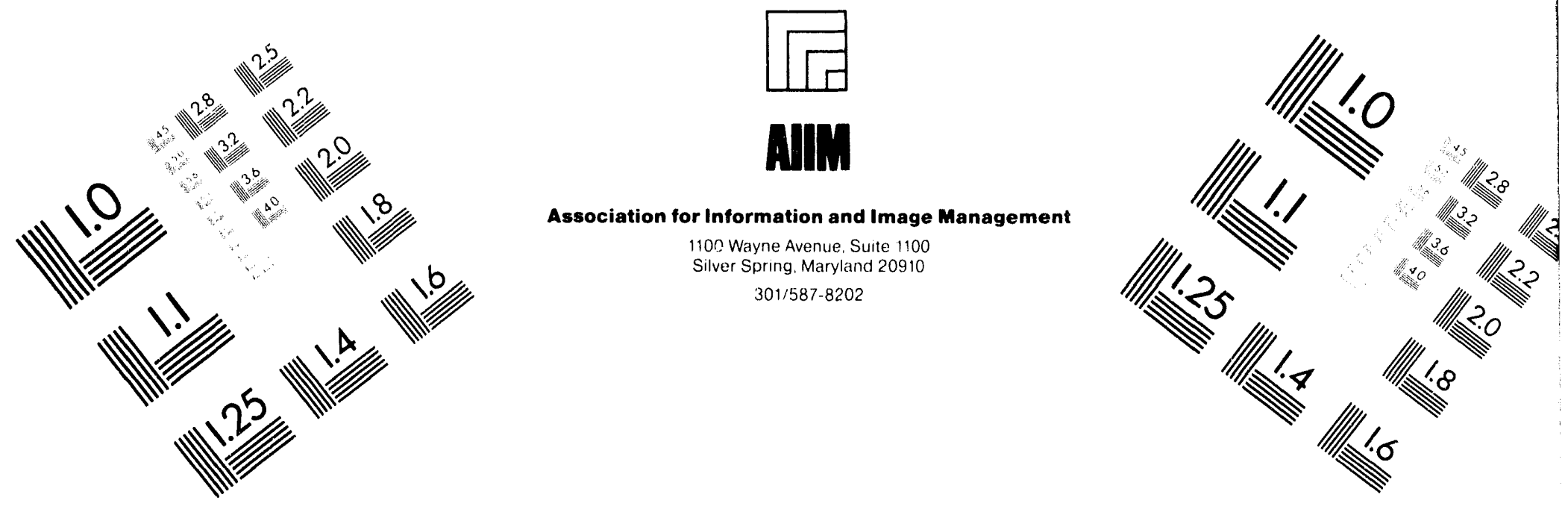

\title{
Centimeter
}

$\left.\right|_{1}$ Inches
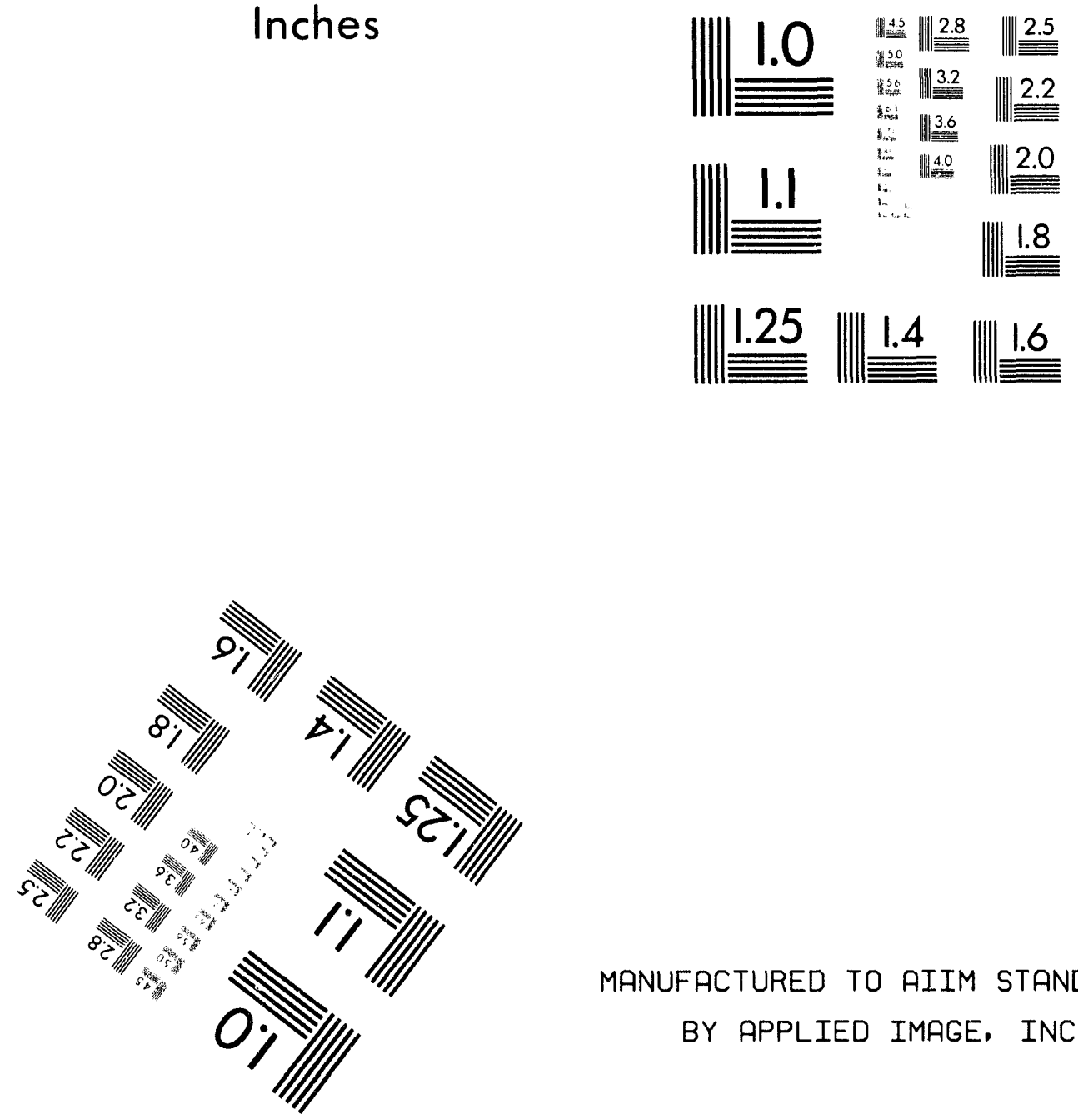

MANUFACTURED TO AIIM STANDARDS

BY APPLIED IMAGE. INC.

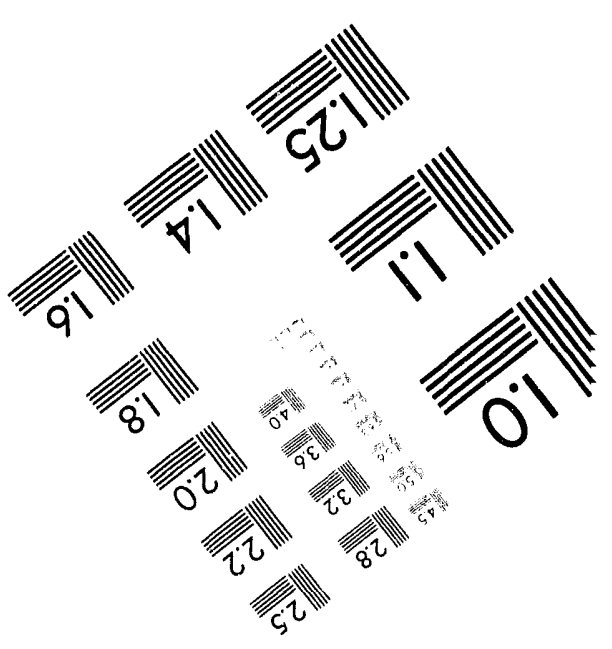



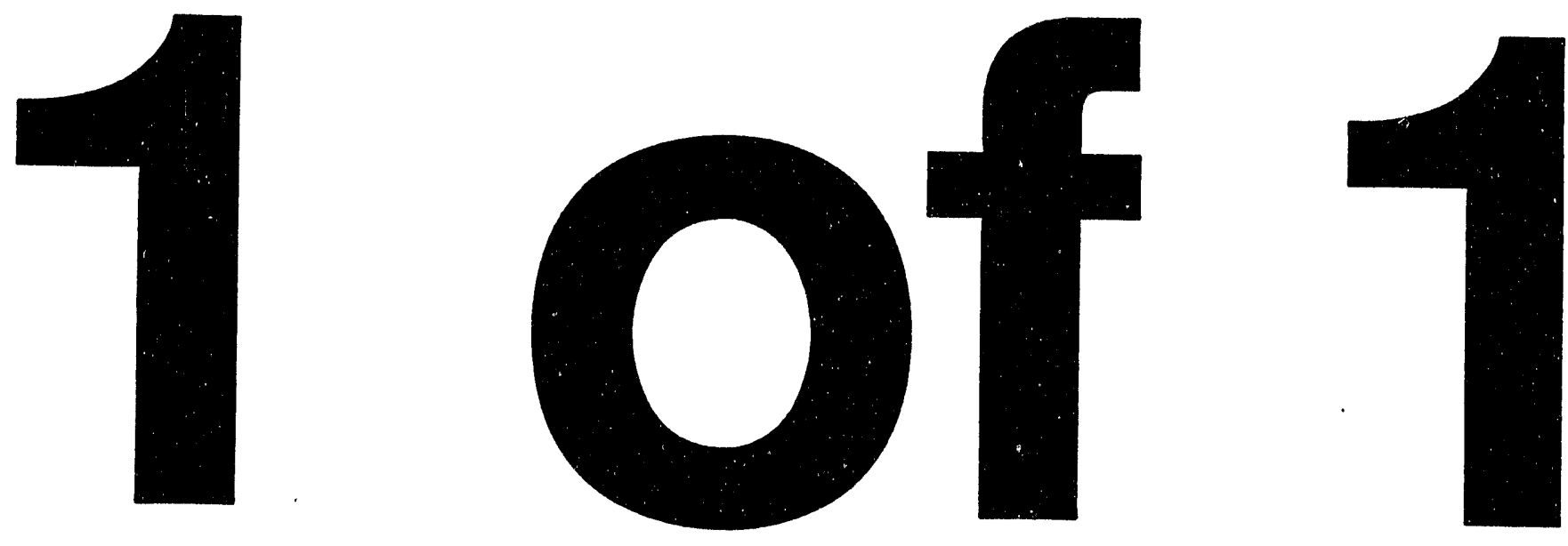

11 


\section{Sage Grouse on the Yakima Training \\ Center: A Summary of Studies \\ Conducted During 1991 and 1992}
L. L. Cadwell
M. A. Simmons
J. L. Downs
C. M. Sveum

April 1994

Prepared for the U.S. Department of the Army under a Related Services Agreement with the U.S. Department of Energy

Contract DE-AC06-76RLO 1830

Pacific Northwest Laboratory Operated for the U.S. Department of Energy by Battelle Memorial Institute 


\title{
DISCLAIMER
}

This report was prepared as an account of work sponsored by an agency of the United States Government. Neither the United States Government nor any agency thereof, nor Battelle Memorial Insticute, nor any of their employees, makes any warranty, expressed or implied, or assumes any legal liability or responsibility for the accuracy, completeness, or usefulness of any information, apparatus, product, or process disclosed, or represents that its use would not infringe privately owned rights. Reference herein to any specific commercial product, process, or service by trade name, trademark, manufacturer, or otherwise does not necessarily constitute or imply its endorsement, recommendation, or favoring by the United States Government or any agency thereof, or Battelle Memorial Institute. The views and opinions of authors expressed herein do not necessarily state or reflect those of the United States Government or any agency thereof.

\author{
PACIFIC NORTHWEST LABORATORY \\ operated by \\ BATTELLE MEMORIAL INSTITUTE \\ for the \\ UNITED STATES DEPARTMENT OF ENERGY \\ under Contract DE-AC06-76RLO 1830
}

Printed in the United States of America

Available to DOE and DOE contractors from the

Office of Scientific and Technical Information, P.O. Box 62, Oak Ridge, IN 37831;

prices available from (615) 5;6-8401. FTS 626-8401.

Available to the public from the National Technical Information Service,

U.S. Department of Commerce, 5285 Port Royal Rd., Springfield, VA 22161. 


\title{
Sage Grouse on the Yakima Training Center: A Summary of Studies Conducted During 1991 and 1992
}

\author{
L. L. Cadwell \\ M. A. Simmons \\ J. L. Downs \\ C. M. Sveum(a)
}

April 1994

Prepared for the U.S. Department of the Army under a Related Services Agreement with the U.S. Department of Energy Contract DE-AC06-76RLO 1830

Pacific Northwest Laboratory

Richland, Washington 99352

(a) Department of Fisheries and Wildlife, Oregon State University, Corvallis, Oregon. 


\section{Summary}

Pacific Northwest Laboratory (PNL) conducted the work reported here as part of a study for the U.S. Department of the Army on sage grouse ecology at the Yakima Training Center (YTC), Yakima, Washington. The YTC sage grouse population is one of only two remnant populations of sage grouse remaining in the state of Washington. Sage grouse are considered candidates for listing as a state threatened species.

The purpose of the work was to identify sage grouse population characteristics, habitat preferences, and land areas used by sage grouse to assist YTC environmental management staff and military training personnel in both managing sage grouse and planning training activities. The ultimate objective is to protect sage grouse and sage grouse habitat without compromising military training objectives.

The sage grouse population on the YTC is small (estimated at approximately 300 to 500 birds), but appears to have remained stable during the past few years. Two distinct subpopulations of grouse appear to exist, each occupying a distinct geographical region and using separate lek areas. Nesting and brooding hens select for long angle slopes and moderate elevations, which places the birds in preferred troop-training areas. The greatest potential impact of training activities on sage grouse seems to be related to habitat loss, although disturbance at leks during the breeding season also could have major impacts on breeding success.

The creation of habitat maps for the YTC showing vegetation features most valued by sage grouse is recommended because it would provide habitat managers and military training planners with a means to protect grouse habitat while making training assignments. An analysis of sage grouse habitat quality, as impacted by training activity, would also assist habitat managers in making decisions regarding habitat restoration and protection. 


\section{Acknowledgments}

This work was funded by the U.S. Department of the Army through a Related Services Agreement with the U.S. Department of Energy under Contract DE-AC06-76RLO 1830. Mr. R. W. Hanna, Chief of the Environmental and Natural Resources Division at Ft. Lewis, was instrumental in obtaining funding for the project.

Numerous Army and civilian personnel assisted in various aspects of the study. The Yakima Training Center (YTC) base commanders Lt. Col. R. Nelson during the initiation of the study and later Lt. Col. E. Horton, and Range Control officers J. H. Hofmann and J. Reddick provided logistical support and invaluable information required to work effectively on the YTC. J. Stephenson, Fisheries and Wildlife Biologist at Ft. Lewis, assisted both in the planning phase and in logistical aspects of the study. Margaret Taaffe-Pounds, wildlife biologist at YTC, contributed to many aspects of the study, including planning, logistics, and field support.

The tireless efforts of K. D. Hand, T. Kollasch, A. Leary, and M. LaCroix in trapping and radio tracking sage grouse are gratefully acknowledged. 


\section{Contents}

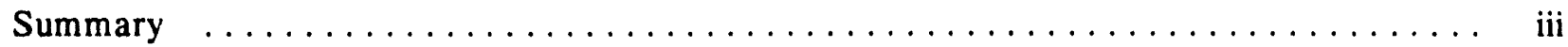

Acknowledgments $\ldots \ldots \ldots \ldots \ldots \ldots \ldots \ldots \ldots \ldots \ldots \ldots \ldots \ldots \ldots \ldots \ldots$

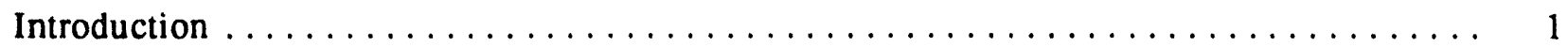

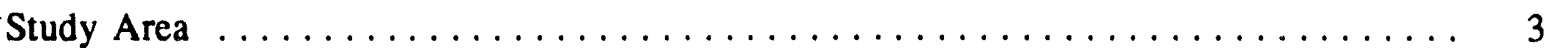

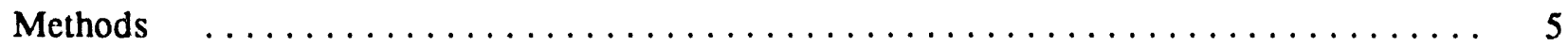

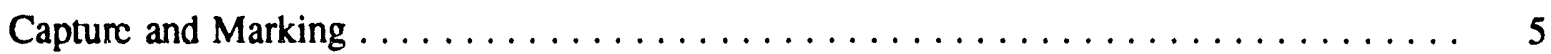

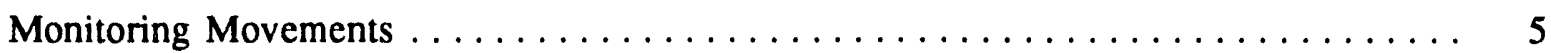

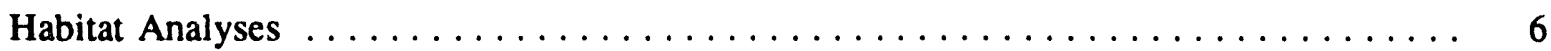

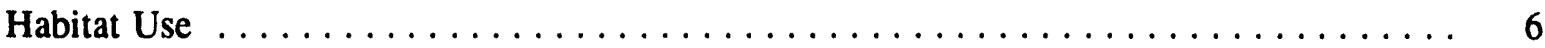

Results and Discussion $\ldots \ldots \ldots \ldots \ldots \ldots \ldots \ldots \ldots \ldots \ldots \ldots \ldots \ldots$

Lck Counts and Population Estimates $\ldots \ldots \ldots \ldots \ldots \ldots \ldots \ldots \ldots \ldots \ldots \ldots \ldots \ldots \ldots \ldots$

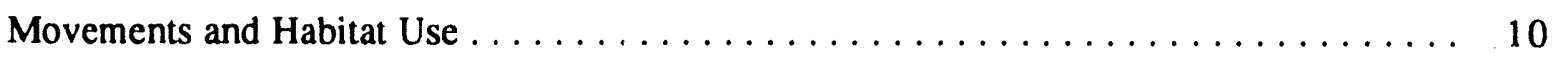

Female Grouse Movements ....................... 10

Male Grouse Movements $\ldots \ldots \ldots \ldots \ldots \ldots \ldots \ldots \ldots \ldots \ldots \ldots$

Distance and Distribution of Nests from Leks $\ldots \ldots \ldots \ldots \ldots \ldots \ldots \ldots$

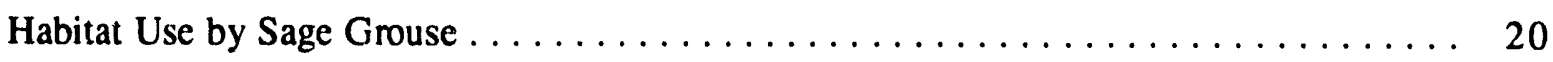

Slope as Element of Habitat Selection by YTC Sage Grouse $\ldots \ldots \ldots \ldots \ldots \ldots$

Elevation as an Element of Habitat Selection by Sage Grouse $\ldots \ldots \ldots \ldots \ldots 21$

Slope Aspect as an Element of Habitat Selection by YTC Sage Grouse . . . . . . 23

Proximity to Water $\ldots \ldots \ldots \ldots \ldots \ldots \ldots \ldots \ldots \ldots \ldots \ldots \ldots$

Use of Soil Types $\ldots \ldots \ldots \ldots \ldots \ldots \ldots \ldots \ldots \ldots \ldots \ldots \ldots \ldots$

Vegetation Types in Sage Grouse Use Areas . . . . . . . . . . . . . 26

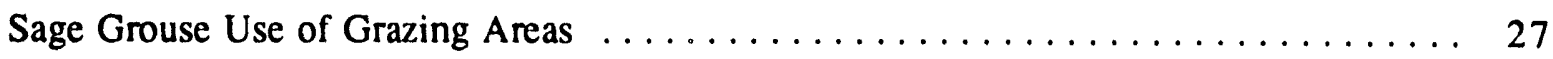

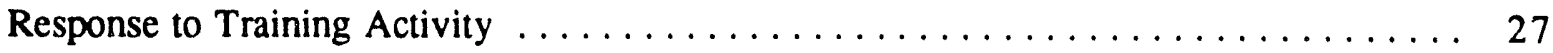


Sage Grouse Use of Areas with Degraded Vegetation . . . . . . . . . . . . . 29

Use of Knapweed Spray Areas $\ldots \ldots \ldots \ldots \ldots \ldots \ldots \ldots \ldots \ldots \ldots \ldots \ldots \ldots$

Conclusions and Recommendations $\ldots \ldots \ldots \ldots \ldots \ldots \ldots \ldots \ldots \ldots \ldots \ldots \ldots \ldots$

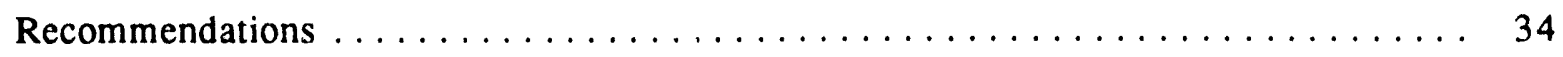

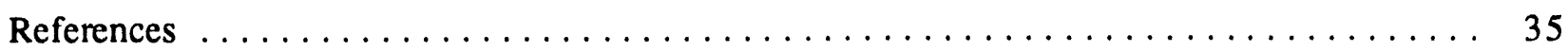

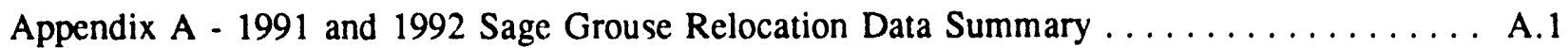

Appendix B - Weekly Maximum Count Data for Male and Female Sage Grouse on

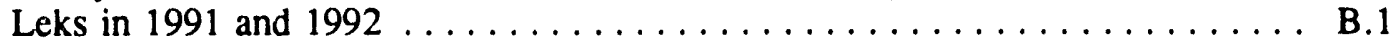

Appendix C - Monthly Average Distances Moved by Male and Female Grouse from Their Lek . . . . . . . . . . . . . . . . . . . . . . . . . C.1 


\section{Figures}

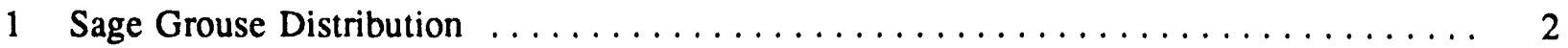

2 Location of Physical Features and Training Areas on the Yakima Training Center $\ldots \ldots \quad 4$

3 A Comparison of 1991 and 1992 Lek Counts with Recent Past Years for Currently Active Leks $\ldots \ldots \ldots \ldots \ldots \ldots \ldots \ldots \ldots \ldots \ldots \ldots \ldots \ldots \ldots$

41991 Seasonal Locations for Female Sage Grouse Rèlative to Leks $\ldots \ldots \ldots \ldots \ldots \ldots$

51992 Seasonal Locations for Female Sage Grouse Relative to Leks $\ldots \ldots \ldots \ldots \ldots \ldots$

6 Sage Grouse Locations on the Yakima Training Center by Geographic Region as Distinguished by Northem and Southem Leks $\ldots \ldots \ldots \ldots \ldots \ldots \ldots \ldots \ldots$

7 Seasonal Land Use Patterns for Two Female Sage Grouse from Range 19 Lek $\ldots \ldots \ldots 16$

81991 Seasonal Lánd Use Patterns for Two Male Sage Grouse from Range 10 Lek $\ldots \ldots 17$

9 Buffer Zones Centered on Leks for 1990, 1991, and 1992 Sage Grouse Nest Locations ........................................... 19

10 Sage Grouse Locations Relative to Grazing Units $\ldots \ldots \ldots \ldots \ldots \ldots \ldots$

111992 Sage Grouse Use on Summer Habitat and 1992 Degraded Areas Relative to

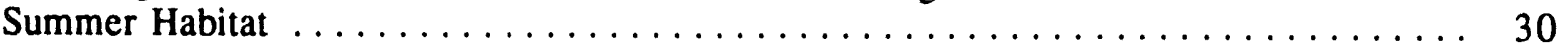




\section{Tables}

1 Maximum Number of Sage Grouse Observed at Leks on the Yakima Training

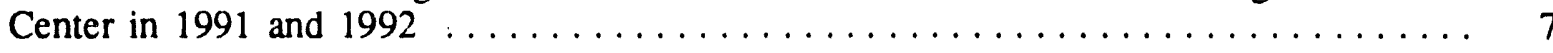

2 Average Distance from Lek for Yakima Training Center Sage Grouse During

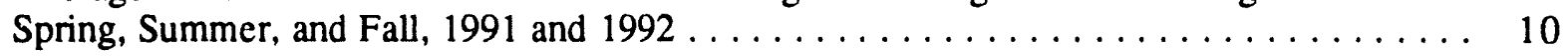

3 Distances of 1990 to 1992 Sage Grouse Nests from Leks for Yakima Training

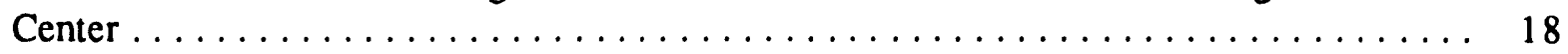

4 Slope Preferences of Sage Grouse for 1991 and $1992 \ldots \ldots \ldots \ldots \ldots \ldots \ldots \ldots$

5 Elevation Preferences of Sage Grouse for 1991 and $1992 \ldots \ldots \ldots \ldots \ldots \ldots 2$

6 Slope Aspect Preferences of Sage Grouse for 1991 and $1992 \ldots \ldots \ldots \ldots \ldots \ldots$

7 Chi-Square Values for Distribution of Sage Grouse Locations Within and Beyond $1 \mathrm{~km}$ from Major Streams on the Yakima Training Center $\ldots \ldots \ldots \ldots \ldots \ldots \ldots$

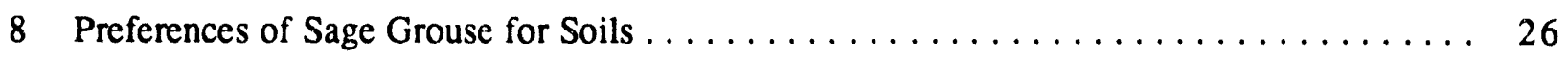

9 Chi-Square Test Results for Sage Grouse Selection of Knapweed Spray Areas

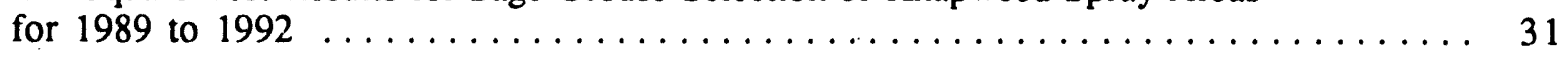




\section{Introduction}

This report summarizes and discusses results obtained from the Yakima Training Center (YTC) sage grouse study during 1991 and 1992. Pacific Northwest Laboratory(a) conducted the study for the U.S. Department of the Army to provide basic ecological information on YTC sage grouse, a technical basis for sage grouse management decisions, and, if warranted, related training restrictions that could be implemented to further protect sage grouse and their critical habitats.

Sage grouse (Centrocercus urophasianus) in the westem plains of North America were once widely distributed, and the birds were abundant. Braun (1993) reported that the birds once occupied at least 14 western states and three Canadian provinces, but have since been eliminated, or nearly so, from five states and British Columbia. He reported that populations in several other states have been "greatly reduced" and in Alberta, North Dakota, Saskatchewan, and South Dakota populations can only be considered marginal. The western subspecies of sage grouse $(C$. u. phaios) occurs only from central and eastem Washington south to southeastem Oregon (Johnsgard 1973). Crawford and Lutz (1985) reported that the range of sage grouse in Oregon decreased from 1900 to 1940 to about onehalf, and since 1940 , populations had declined by about $60 \%$.

During the last four decades, the distribution of sage grouse in Washington has steadily declined (Figure 1b) (Yocom 1956; Pedersen 1981). Although no "official" estimates of the Washington State sage grouse population have been made, it is probably safe to assume that there are, at most, a few thousand birds still residing in remnants of the birds' former range. This reduction in the distribution of sage grouse in Washington has been attributed to the removal of sagebrush over large areas for agricultural and other purposes (Yocom 1956). The current distribution of sage grouse in Washington (Figure 1b) consists of a northern population that occupies fragmented habitat in Douglas County and the YTC population in more or less contiguous habitat in Kittitas and Yakima counties. A few additional birds may exist in northern Benton County on the U.S. Department of Energy's Hanford Site and/or adjacent private lands. Currently, the YTC supports not only the most southern population of this species in Washington, but probably the largest population of sage grouse left on federally owned lands in Washington.

Hunting sage grouse in Washington was halted in 1988 because of the reduced distribution of the birds and the general lack of biological information on this species in Washington. Currently, this species is listed by the U.S. Fish and Wildlife Service as a candidate species for the threatened and endangered list in Washington and by the Washington State Department of Wildlife (WDW) as a state candidate for threatened and endangered species listing. A memorandum (8/18/89) from the Deputy Assistant Secretary of the Army (Installations and Housing) stated that "candidate species and those proposed for listing will be treated as listed species when managing the natural resources or supporting military mission requirements."

This report summarizes study results from 1991 and 1992 on the ecology, habitat preferences, and responses of sage grouse to troop training activity on the YTC. The 1991 field study was conducted as an extension of the work reported by Eberhardt and Hofmann (1991). In 1992, a 2-year

study was initiated on the breeding ecology of sage grouse on the YTC. The results of that study,

(a) Operated by Battelle Memorial Institute for the U.S. Department of Energy under Contract DEAC06-76RLO 1830. 


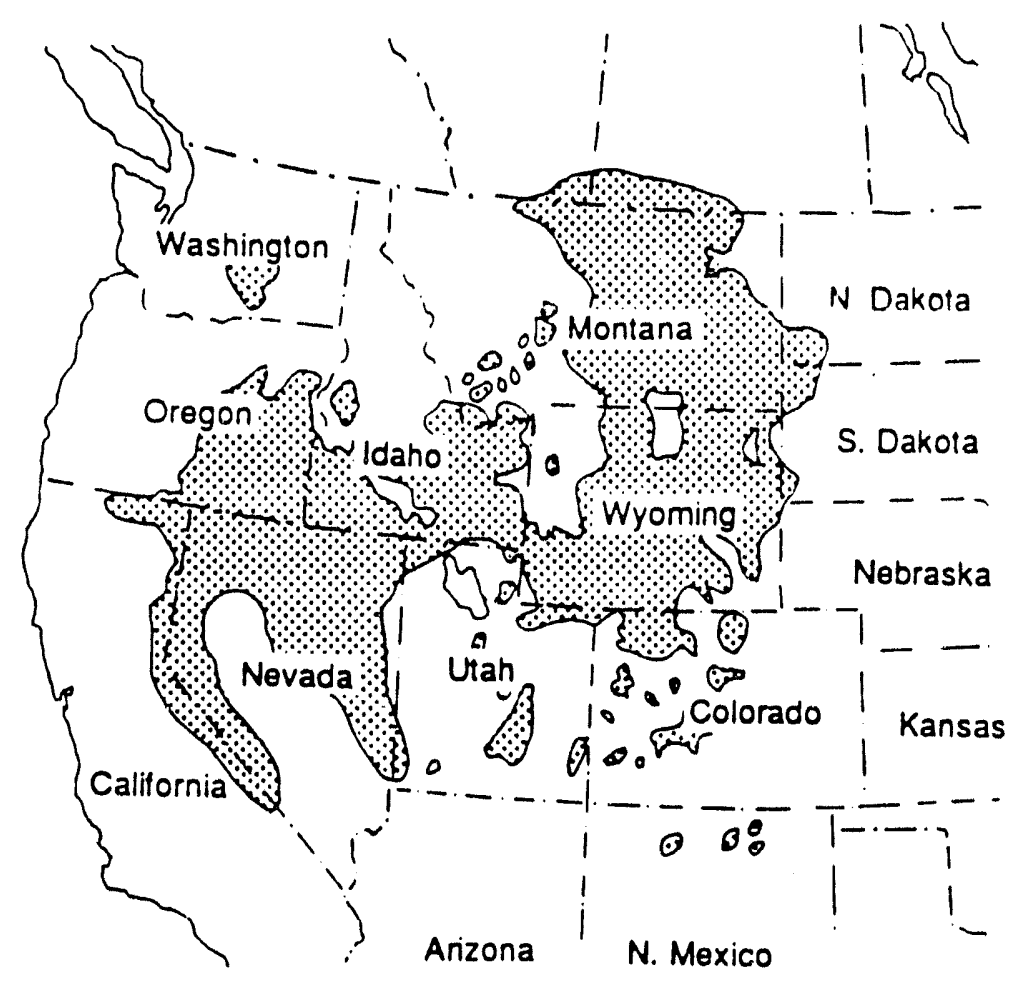

a) In Westem States (From Johnsgard 1973)

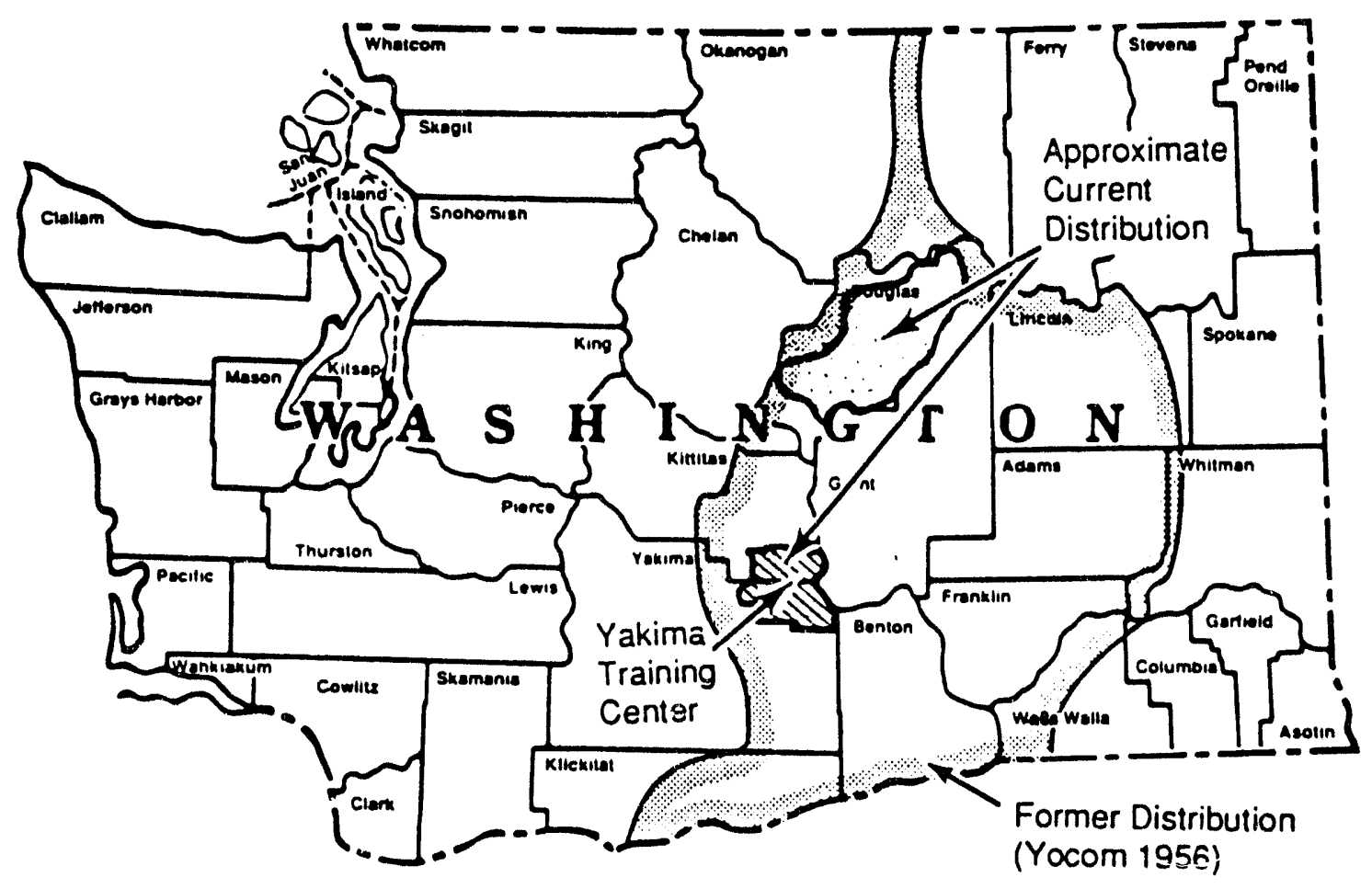
b) In Washington (From Yocom 1956 and personal communication, R. Friesz, Washington
Department of Wildlife)

Figure 1. Sage Grouse Distribution 
with emphasis on nesting and brood rearing, will be drafted as an Oregon State University master's thesis. Data from the 1992 field work summarized here include Geographical Information System (GIS) analyses of sage grouse location data exclusive of nesting and brood-rearing.

Specific objectives of this study were to 1) obtain information on the distribution of sage grouse on the YTC and their seasonal use of specific areas, 2) identify movements of sage grouse on the YTC, 3) identify habitat preferences for sage grouse on the YTC, and 4) provide management recommendations.

\section{Study Area(a)}

The 1,058- $\mathrm{km}^{2}$ YTC is located in southcentral Washington in Yakima and Kittitas counties approximately $11 \mathrm{~km}$ north of Yakima. The YTC is bordered by the Columbia River on the east, interstate highway I-82 on the west, the Saddle Mountains on the north, and Moxee Valley on the south (Figure 2). Umtanum Ridge, which bisects the YTC east to west, reaches elevations of 1,249 m. The lowest elevation on the YTC is $183 \mathrm{~m}$. Prominent physical features and training areas are shown in Figure 2.

The climate of the area is characterized by hot, dry summers and cold, dry winters. The annual precipitation is approximately $20 \mathrm{~cm}$ per year. Temperatures range from $-4^{\circ} \mathrm{C}$ in January to $40^{\circ} \mathrm{C}$ in July.

The YTC supports one of the larger contiguous tracts of native shrub-steppe vegetation left in Washington. Stands of big sagebrush (Artemisia tridentata) occur throughout the area. On relatively undisturbed areas, bluebunch wheatgrass (Agropyron spicatum) is the dominant grass; however, cheatgrass (Bromus tectorum) and knapweed (Centaurea sp.) predominate in heavily disturbed areas.

The YTC is well suited for training troops for desert warfare and is used by both active and reserve U.S. Army military components for troop maneuver exercises and weapons firing. In 1991, over 640,000 man-days of use (approximately 1800 soldiers per day) and nearly 10,000 vehicle-days occurred on the YTC. Training intensity was reduced by about a factor of 10 in 1992.

This report discusses the methodology used in this study, presents results, and provides conclusions and management recommendations.

(a) From Eberhardt and Hofmann (1991). 

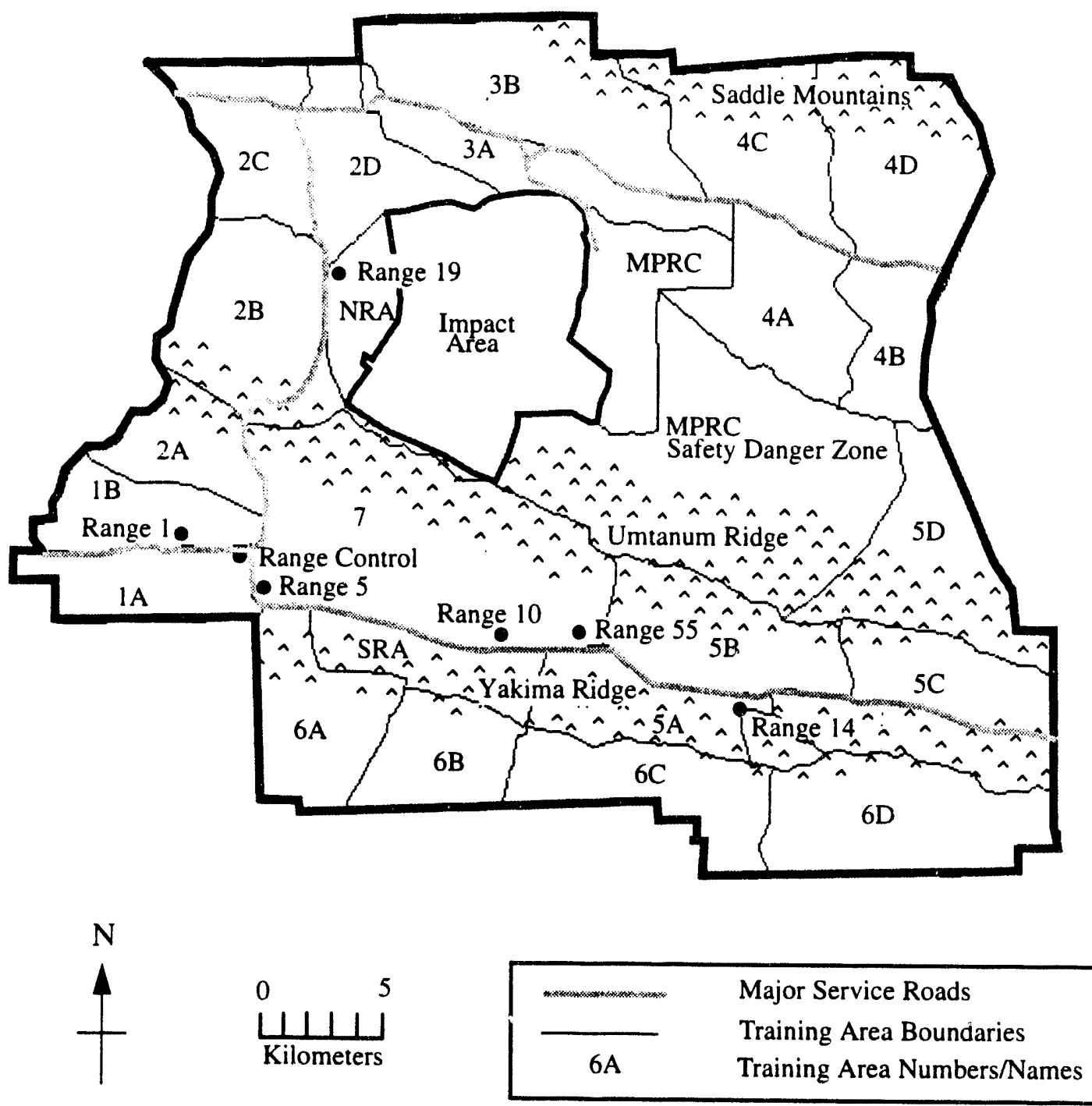

Figure 2. Location of Physical Features and Training Areas on the Yakima Training Center 


\section{Methods}

\section{Capture and Marking}

During the breeding seasons of 1991 and 1992, two methods were used to capture sage grouse on and near the leks. Initially, net launchers were positioned on leks to capture birds, but that method was soon replaced by nighttime hand netting. Roads traversing the leks were driven at night, and sage grouse were located with 1,000,000 candle-power spotlights. Once an individual or a group of sage grouse was located, a team of two researchers approached the bird on foot. One member of the capture team focused the spotlight on the bird while the other member used a long-handled dip net to capture the grouse (Giesen et al. 1982). Recordings of loud background noises (e.g., a helicopter noise) were used to confuse the bird and to hide noises made by the capture team during the approach.

Once captured, the sex of the bird was recorded, and its age was estimated by observing the wear pattern on the outer two primary feathers of the wing (Beck et al. 1975). All sage grouse captured in 1991 and 1992 were equipped with small battery-powered radio transmitters that were glued and sewn to a herculite poncho (Amstrup 1980). The size of the hole in the neck of the poncho was individually cut for each bird, and the poncho was slipped over its head.

\section{Monitoring Movements}

Although radio-equipped sage grouse were located from both ground and air, most of the monitoring effort was ground based. Radio-tracking grouse from the ground was accomplished by first locating the general locale of the marked bird from a vehicle equipped with an omni-directional antenna. The bird was then approached on foot using a hand-held yagi antenna, and its location was determined. Often the marked bird was visually located during this procedure. The location of the bird was recorded in Universal Transverse Mercator (UTM) coordinates determined with a Magellan Global Positioning System unit. Additional data recorded included the activity of the bird, time, air temperature, percent cloud cover, wind speed, and vegetation cover.

Four permanent ground-tracking towers were used to locate sage grouse when they were in the Impact Area during the 1991 field season. Additionally, since sage grouse on the YTC often make lengthy, erratic movements, which made relocating them from the ground very difficult, a fixed-wing aircraft was used as weather and air-space access permitted to locate birds that could not be relocated from the ground. Eberhardt and Hofmann (1991) described the methods for obtaining grouse locations from the towers and the procedures used for aerial radio-tracking.

Attempts were made to locate marked grouse twice weekly during spring and summer 1991 and, due to the larger number of marked birds, weekly for the same period in 1992. Efforts during the fall and early winter were made approximately weekly. Drifted snow sometimes precluded access from the ground to areas occupied by the grouse. Birds were sometimes in areas that were inaccessible, either because of rugged terrain or, more frequently, because human access was restricted because of either unexploded ordnance or military training sessions. 


\section{Habitat Analyses}

For habitat use analyses we used Geographical Resource and Analysis Support System (GRASS) software (U.S. Army Corps of Engineers 1987) on a SUN computer. GRASS is a publicdomain, raster-based software package developed by the U.S. Army Corps of Engineers' Construction Engineering Research Laboratory, Champaign, Illinois.

\section{Habitat Use}

We used GRASS software to analyze sage grouse location data relative to habitat characteristic map layers including slope, elevation, aspect, distance to streams, and use of knapweed spray areas. We calculated the proportion of radio locations of marked grouse that fell within the several habitat categories. Chi-square analyses and Bonferroni confidence intervals were used on each of the four input maps to evaluate whether marked grouse used habitat in proportion to habitat availability and, if not, whether some habitats were either preferred or avoided (Neu et al. 1974). Data for all marked individuals were most often grouped by sex and season for specific analyses.

Analyses for slope were based on $5^{\circ}$ intervals between $0^{\circ}$ and $55^{\circ}$. One hundred meter bands between $100 \mathrm{~m}$ and $1300 \mathrm{~m}$ were used to divide sage grouse location data for analyses. Aspect sectors were each $45^{\circ}$ with the initial sector centered on true north. Sage grouse use was compared among slope intervals, elevation bands, and aspect sectors. Distance from streams was identified relative to a $1-\mathrm{km}$ band around class 3,4 , and 5 streams, and comparisons were made on grouse use of areas within and outside of the $1-\mathrm{km}$ band. Knapweed spray areas were digitized on a map layer, and grouse preference/avoidance was analyzed by comparing use of spray areas to use of preferred habitat on the YTC (0 to $5^{\circ}$ slope and 600 - to 800 -m elevations). 


\section{Results and Discussion}

Fifty-eight sage grouse were captured and fitted with radio transmitters during 1991 and 1992. For 1991, 13 grouse (8 males and 5 females) captured in winter were monitored in addition to 6 females captured in 1990 that continued to carry operating transmitters (Eberhardt and Hofmann, 1991). A greater trapping effor in 1992 resulted in 45 birds, all females, being captured and fitted with transmitters. In addition to the birds captured in 1992, we monitored movements of two females captured in previous years. Thus, the total number of birds monitored was 19 in previous years and 47 in 1992. Appendix A summarizes the sex, capture location, and relocation data for the birds monitored during 1991 and 1992.

During 1991, the 19 monitored birds were located by radio-telemetry a total of 677 times for an average of 36 locations per bird. In 1992, the number of female grouse locations (638) was similar to 1991, but with a much larger number of radio-marked birds (47). The average number of locations per bird was 14 .

\section{Lek Counts and Population Estimates}

Lek counts on the YTC have been conducted for a number of years to monitor breeding season numbers of male sage grouse. Eberhardt and Hofmann (1991) summarized past lek count data and provided data for 1989 and 1990 . We continued the lek counts in 1991 and 1992 using the methods described by Eberhardt and Hofmann (1991).

Although data are presented for both male and female grouse (Table 1 and Appendix B), it is the male that attends the lek for the duration of the lengthy 3-month strutting period (Patterson 1952) and is most visible. The use of lek counts as an index to population censusing was recommended by Patterson (1952) and further evaluated and refined by Jenni and Hartzler (1978). Emmons and Braun (1984), however, argue against using counts of males on leks independently and

Table 1. Maximum Number of Sage Grouse Observed at Leks on the Yakima Training Center in 1991 and 1992

\begin{tabular}{|c|c|c|c|c|c|c|}
\hline & \multicolumn{3}{|c|}{1991} & \multicolumn{3}{|c|}{1992} \\
\hline & Total $^{(a)}$ & Males & Females & Total ${ }^{(a)}$ & Males & Females \\
\hline Range 19 & 70 & 62 & 23 & 68 & 36 & 38 \\
\hline Range 15 & 5 & 5 & 2 & 12 & 0 & 0 \\
\hline Range 10 & 17 & 16 & 8 & 15 & 9 & 7 \\
\hline Range 5 & 35 & 33 & 3 & 15 & 15 & 0 \\
\hline Range 55 & 31 & 31 & 6 & 30 & 21 & $1 \%$ \\
\hline Beller Drop Zone & 14 & 14 & 4 & 15 & 14 & 5 \\
\hline Squaw Creek & 20 & 12 & 12 & 15 & 14 & -1 \\
\hline Total & 192 & 173 & 58 & 170 & 109 & 63 \\
\hline
\end{tabular}

(a) Total maximum is the total count of males and females present on the day of peak lek attendance and not the sum of the maximum number of males and maximum number of females. 
point out that a relationship between lek counts and population size has not been demonstrated. We believe, however, that with a small population that is geographically confined to a relatively small land area, that lek counts are useful as population indices and can be used to approximate population size.

Figure 3 compares our 1991 and 1992 count data (males) for currently active leks on the YTC with data taken from Eberhardt and Hofmann (1991) for several YTC leks. Male count data for the major YTC leks in 1991 and 1992 are similar to recent years. In 1991, a slight increase over 1989 and 1990 was apparent, but the 1992 count returned to the approximate level of previous years. Table 1 provides the maximum number of males, females, and total grouse counted for each lek during the 1991 and 1992 breeding seasons. Males tend to reach their peak numbers on leks after the peak in female attendance (Jenni and Hartzler 1978). Since males remain at the leks for much of the breeding season, whereas females make only a relatively brief visit, consecutive counts are "male biased," and thus, the time at which the combined sexes count peaks is most influenced by the peak in numbers of males. (Appendix B provides weekly counts by lek for male and female sage grouse for 1991 and 1992.)

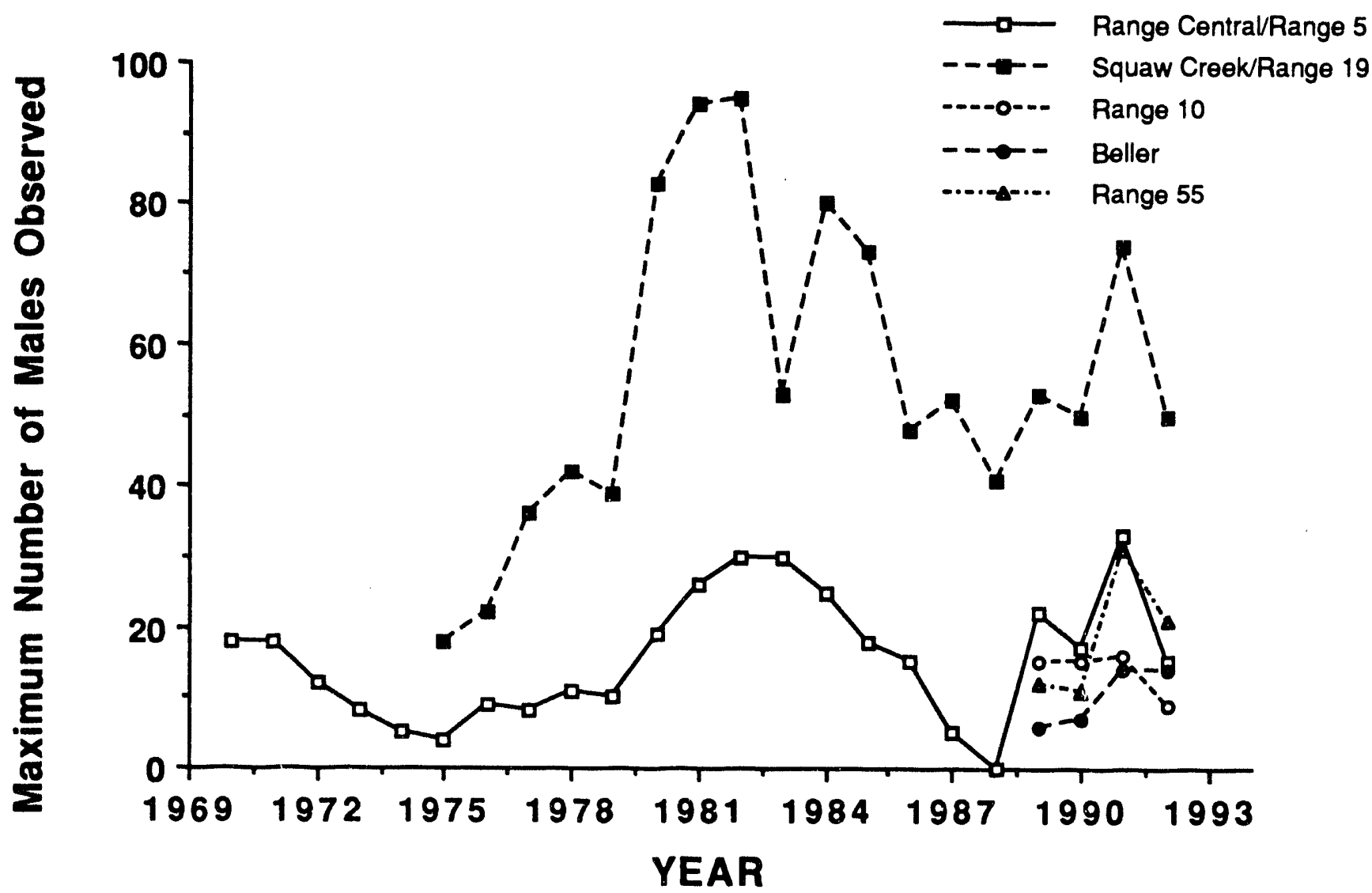

Figure 3. A Comparison of 1991 and 1992 Lek Counts (males) with Recent Past Years for Currently Active Leks 
Although we do not view lek count data as an accurate estimator of population size, the data can be used to approximate population size. We made a lower limit estimate of the sage grouse population by applying several conservative assumptions to the lek count data. Those assumptions are as follows:

- The maximum number of male grouse observed at any lek during the breeding season is equal to the total number of males using that lek.

- All leks were located and accurately counted.

- The sex ratio is one-to-one.

By applying these assumptions to the 2-year average of the maximum number of males counted (141) and multiplying by 2 to account for an equal number of females, we get 282 . To bracket the conservative estimate, we have alternatively assumed that:

- only $90 \%$ of the males on any give lek were observed (as suggested by Jenni and Hartzler 1978)

- $60 \%$ of the population consists of females (Rogers 1964)

- $10 \%$ of the males were missed in the census because one or more minor leks may have not been located.

Calculations based on these assumptions yield a population estimate of:

$(141 / 90) \times 100=157$ known lek males

$(157 / 40) \times 60=236$ known lek females

$157+236=393$ known lek estimate

$393 \times 0.10=39$ additional birds potentially attributable to unknown lek(s)

$393+39=432$ grouse.

Although it is possible that one or more minor leks exist at unknown locations on the YTC, we view it as extremely unlikely that more than $10 \%$ of the known lek-attending population exists at unknown locations. We base this opinion on the results of aerial surveys conducted by helicopter in 1989 and 1990 by Eberhardt and Hofmann (1991) and additional surveys in 1991 and 1992 conducted as part of this survey. In 1991, several displaying males were observed in grid square 1880(a) from the air, but were not subsequently located from the ground.

These estimates derived from lek counts do agree in magnitude with general numbers of sage grouse on the YTC that we, as biologists, are comfortable with based on several years of field observation. This exercise suggests that the 1991/1992 population of sage grouse on the YTC is small, probably only a few hundred birds (300 to 500) at most.

(a) Yakima Firing Center Special Map, Series V791S, Edition 4DMA. 


\section{Movements and Habitat Use}

Several aspects of habitat use by sage grouse on the YTC were analyzed using GRASS software to better understand seasonal habitat requirements of the grouse as a basis for establishing grouse management practices and to coordinate grouse management with training area use and schedules. Leks, as traditional breeding areas of critical importance to sage grouse, have been individually identified and recommended for protection on the YTC (Eberhardt and Hofmann 1991). Thus, we chose to use the lek location as a basis for several analyses of sage grouse movements and distributions on the YTC. We analyzed sage grouse radio-telemetry data to determine the use of land areas relative to leks during spring, summer, and fall. Initial attempts to view sage grouse locations monthly were not productive. Seasonal patterns of land use became evident when we grouped months into "seasons," that included "spring" as March, April, and May, "summer" as June, July, and August, and "fall" as September, October, and November.

\section{Female Grouse Movements}

Few radio-telemetry "sitings" of female sage grouse were made at the leks. It appears that female YTC sage grouse in 1991 and 1992 visited the leks briefly for breeding and then dispersed to nesting areas. Dalke et al. (1960) described the arrival of females at leks as "...one of rapid buildup." The distance from iek to area occupied by YTC females averaged $5 \mathrm{~km}$ for spring and increased to between 6 and $7 \mathrm{~km}$ for summer and fall (Table 2). For populations of sage givuse that did not appear to migrate (YTC sage grouse appear to be non-migratory), leks are normally near nesting areas (Autenrieth 1981). The distances from lek to areas occupied are similar to those found by Schroeder(a) in 1992 for the Douglas County population. Douglas County hens were located an average of about $3 \mathrm{~km}$ from their leks in March, but then moved out to an average distance of about $6 \mathrm{~km}$, which they then maintained from April through October. The Douglas County sage grouse population occupies habitat fragmented by tilled agricultural lands. In contrast, YTC sage grouse habitat is not broken by agriculture, but rather, contains a patchwork pattern of lightly disturbed sagebrush-steppe, interspersed with areas that are in various stages of succession as a result of bums and physical disturbance. Some of the heavily disturbed areas have been replanted to a mixture of

Table 2. Average Distance from Lek (capture site) for Yakima Training Center Sage Grouse During Spring, Summer, and Fall, 1991 and 1992

Average(a) Distance (km) from Lek

\begin{tabular}{|c|c|c|}
\hline Spring & Summer & Fall \\
\hline $\begin{array}{ll}5.2 & (0.7) \\
4.9 & (0.4) \\
4.4 & (0.9)^{(b)}\end{array}$ & $\begin{array}{l}6.9(0.9) \\
6.8(0.8) \\
12.6(0.8)\end{array}$ & $\begin{array}{ll}6.3 & (1.7) \\
6.7 & (0.9) \\
7.2 & (1.5)\end{array}$ \\
\hline
\end{tabular}

Females, 1991

Females, 1992

Males, 1991

$$
4.9(0.4)
$$

$4.4(0.9)(b)$
$12.6(0.8)$
$6.7(0.9)$

$7.2(1.5)$

(a) $95 \%$ confidence interval.

(b) The spring average distance of males from leks includes 2 months (March and April) when males were approximately $2 \mathrm{~km}$ from leks, and 1 month (May) when they were dispersing and were about $10 \mathrm{~km}$ from leks.

(a) Mike Schroeder, Washington State Department of Wildlife, personal communication, October 1993. 
native plant species and range grasses. In spite of the apparent difference in composition and pattern of vegetation at YTC and Douglas County, female sage grouse showed remarkably similar movements from leks.

To identify patterns in the seasonal distribution of grouse from the several active leks on the YTC [see Eberhardt and Hofmann (1991) for a map and description of lek locations], we created GIS-based maps showing female sage grouse relocation positions by lek for the 1991 and 1992 seasons (Figures 4 and 5). Most of the "sitings" of hens from the Range 19 lek (Figures 4a and 5a) occurred near the lek. A few sitings of Range 19 hens occurred near the northem boundary of the YTC; a limited number of hens were sited as far south as Beller Drop Zone. Range 19 birds did not, however, move up (southeast) the Selah Creek valley toward Ranges 5, 10, and 55 where several remaining active leks are located. Range 19 females were not observed frequently on the south side of Yakima Ridge.

Figures $4 \mathrm{~b}, 4 \mathrm{c}$, and $5 \mathrm{c}-\mathrm{f}$ show that hens from Beller Drop Zone and Ranges 5, 10, and 55 had little tendency to cross Umtanum Ridge. These hens did, however, move freely up and down the Selah Creek drainage.

When viewed as a whole, the 1991/1992 relocation data suggest that female sage grouse on the YTC have a high degree of "regional fidelity" with respect to leks, and they make most intensive use of two somewhat distinct geographic areas (Figure 6). One area is a broad, genuly rolling plain that lies north of Umtanum Ridge in the northwest quarter of the YTC. The Range 19 and Squaw Creek leks are centrally located within this area. The second area is the broad Selah Creek Valley running diagonally southeast from Beller Drop Zone, which is located northwest of Range Control to the Creek's headwaters near the center of Training Area 5B. The birds from these two geographic areas (subpopulations) intermingle in the vicinity of Range Control (Figure 2). The Beller and Ranges 5, 10, and 55 leks are located in the Sclah Creek Valley.

The relative isolation of hens in these two geographic areas during spring, summer, and fall (Figure 6) suggests that land management practices, habitat restoration, training activities, and other factors having the potential to impact the sage grouse populations be considered from the perspective that the northem and southern portions of the population are separate entities. Thus, to adequately protect the YTC sage grouse population, management practices need to be developed for each of the two areas.

The GRASS maps were created to examine seasonal movements of individual female sage grouse on the YTC during 1991 and 1992. Female grouse often remained in a limited area for a time period roughly approximating a "season" as we defined it, and then moved to a new location where they again remained for a time. Examples of seasonal land use patterns for two grouse, one from 1991 and one from 1992 are shown Figures 7a and $7 b$.

\section{Male Grouse Movements}

Male sage grouse remain near leks for the duration of the breeding season (Hayden-Wing et al. 1986). Average distances from leks for YTC males in 1991 were $2.2 \mathrm{~km}$ and $1.9 \mathrm{~km}$ for March and April, respectively. These distances are greater than those reported by Eberhardt and Hofmann (1991) for the YTC and greater than the maximum distance for males from leks in Montana and Colorado (Wallestad and Schladweiler 1974; Carr 1967). Males dispersed from leks in May, when the average distance increased to $10.5 \mathrm{~km}$. The distances for summer (June, July, and August) averaged $12.6 \mathrm{~km}$ and showed very little month-to-month variation. The fall average bird-to-lek distance was $7.2 \mathrm{~km}$. The movement pattern of YTC males may be best described as close attendance 


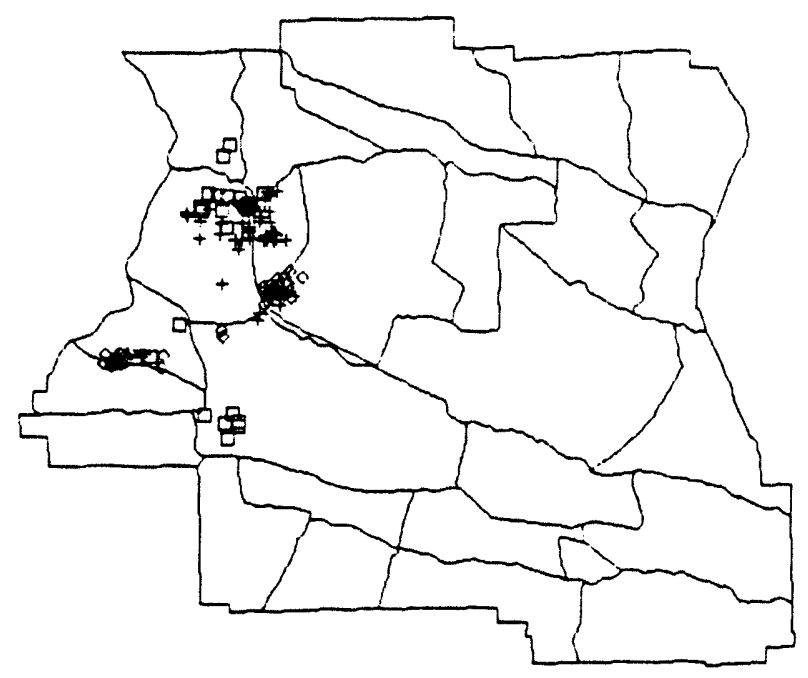

a) Range 19 Lek

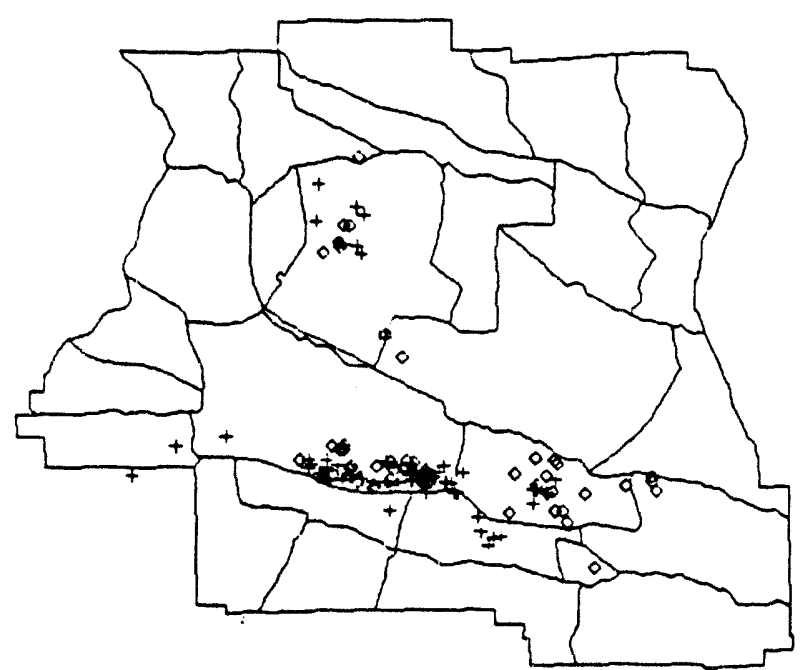

c) Range 55 Lek

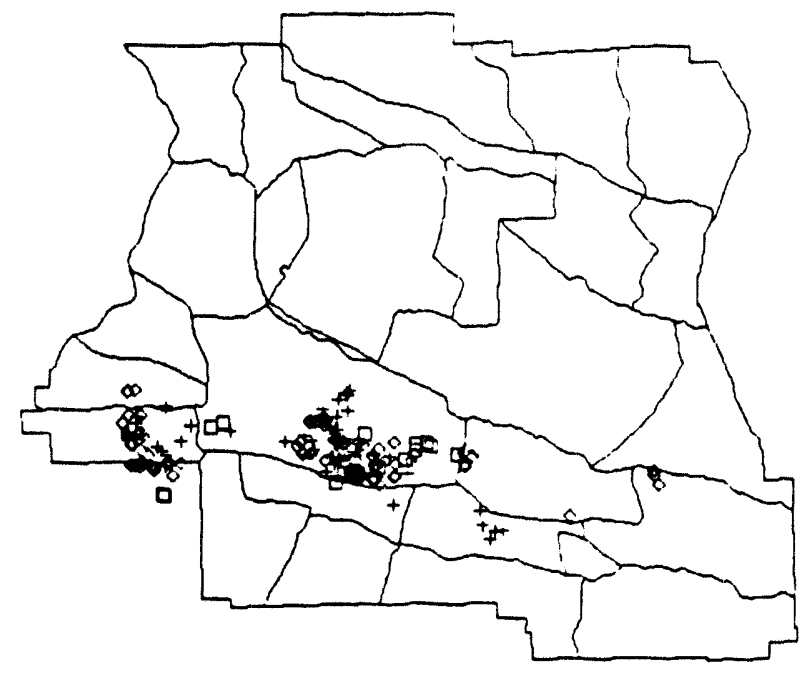

b) Range 10 Lek

$$
\begin{array}{|lll|}
+ & \text { Spring } & \text { Location of Lek } \\
\diamond & \text { Summer } & \\
\square & \text { Fall } & \\
\hline
\end{array}
$$

Figure 4. 1991 Seasonal Locations for Female Sage Grouse Relative to Leks 


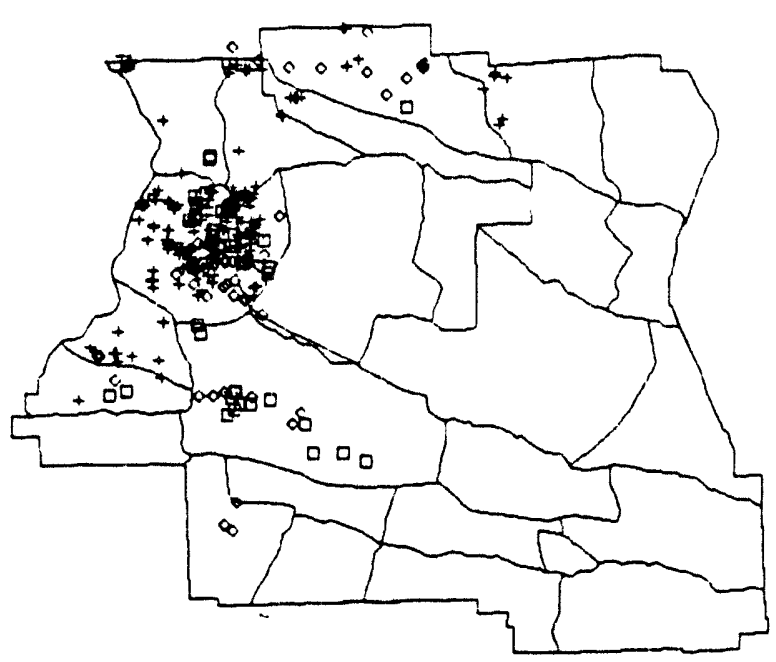

a) Range 19 Lek

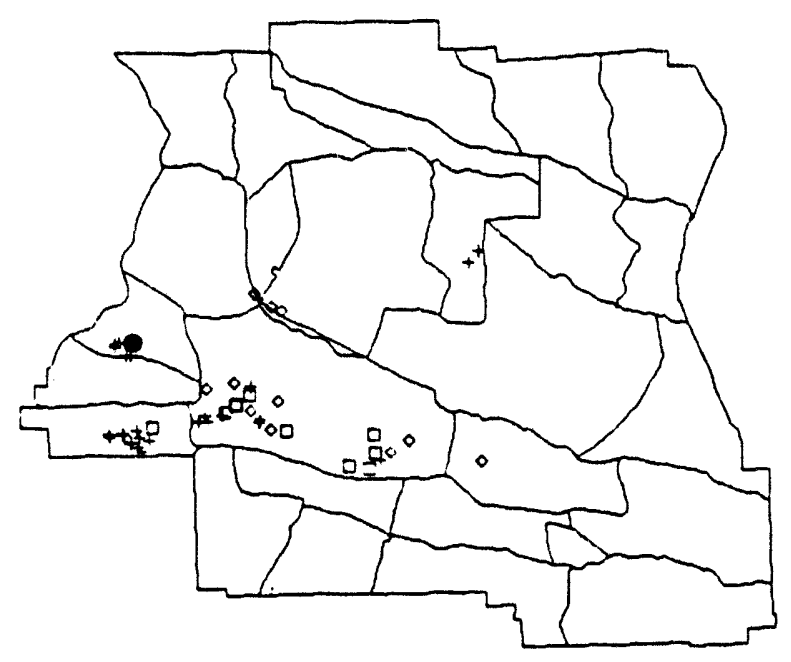

c) Beller Lek

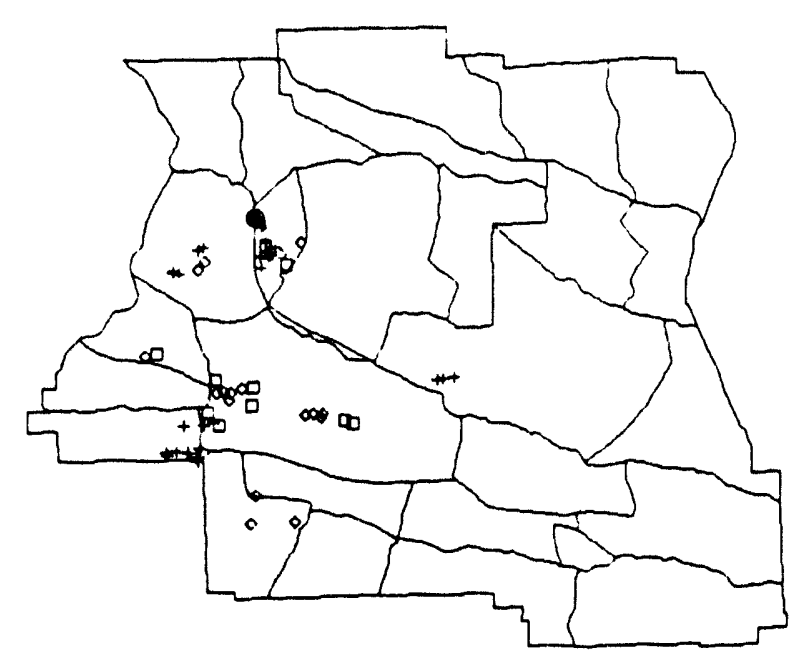

b) Squaw Creek Lek

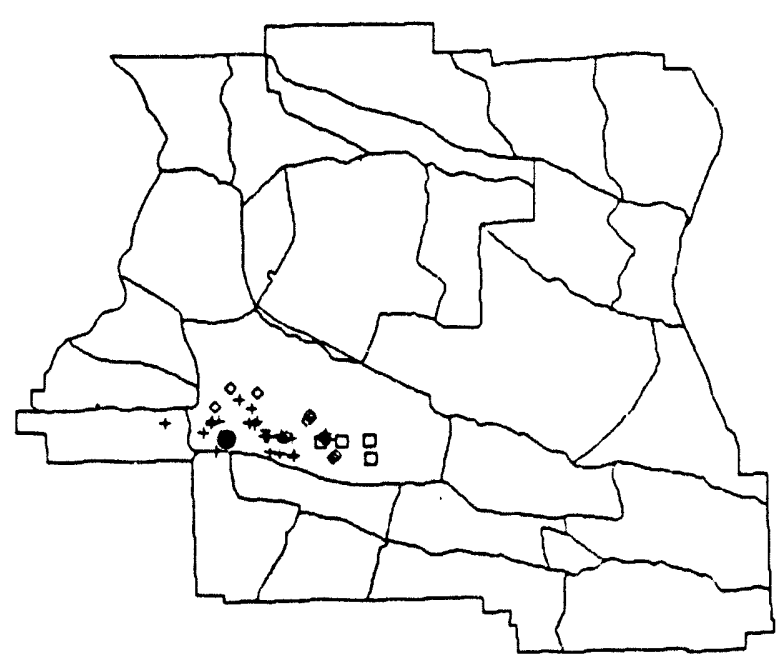

d) Range 5 Lek

$$
\begin{array}{|lll|}
\hline+ & \text { Spring } & \text { Location of Lek } \\
\diamond & \text { Summer } & \\
\square & \text { Fall } & \\
\hline
\end{array}
$$

Figure 5. 1992 Seasonal Locations for Female Sage Grouse Relative to Leks 


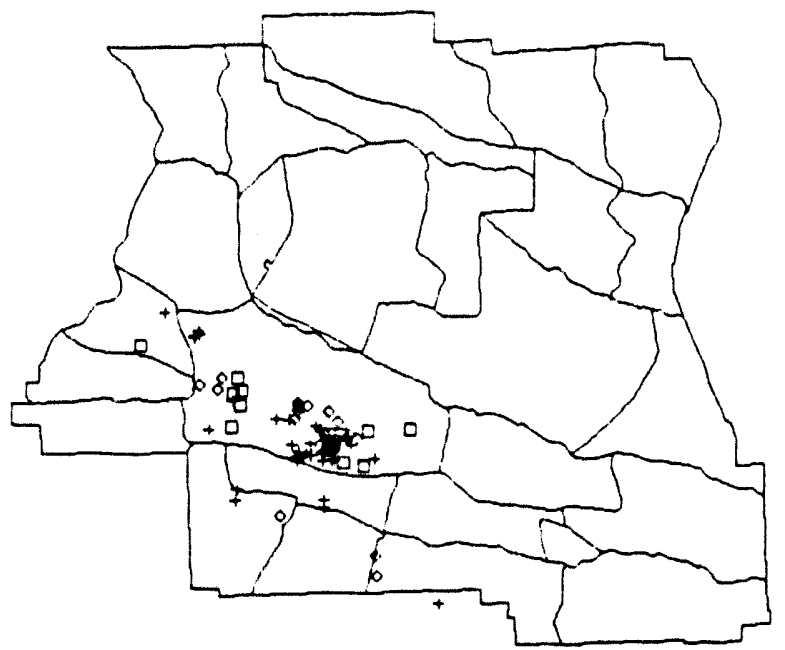

e) Range 10 Lek

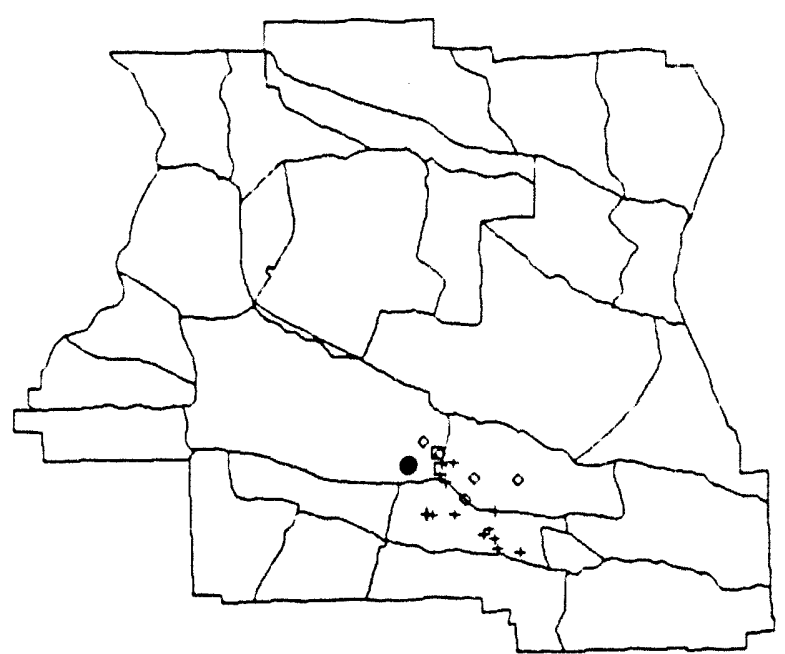

f) Range 55 Lek

$$
\begin{array}{lll}
+ & \text { Spring } & \text { Location of Lek } \\
\diamond & \text { Summer } & \\
\square & \text { Fall } &
\end{array}
$$

Figure 5 (contd). 1992 Seasonal Locations for Female Sage Grouse Relative to Leks

at the leks for March and April, followed by a rapid movement to the "summering area" in May. Connelly et al. (1988) reported that male sage grouse from lowland areas in Idaho moved directly from the leks to summer range in late April or early May. The YTC male grouse, after occupying the slopes, draws, and ridges for most of May, June, and July, began a gradual "migration" back toward the lek in the fall. Connelly et al. (1988) made a similar observation for Idaho sage grouse (sex not distinguished) in which they described the movement to winter range as "...generally slow and meandering..." Because leks are often located near the birds' winter range (Connelly et al. 1988; Autenrieth 1981), our observation that males began a fall movement back toward the leks seems to fit the previously reported pattem. The very limited number of winter (February 1991) location observations (eight) that we made on male grouse showed them to be an average of $2.5 \mathrm{~km}$ from leks.

Males that used leks on Ranges 5, 10, and 55 moved to upland areas in Training Areas 5B, 5C, and 6D where they spent the summer. Eberhardt and Hofmann (1991) observed a similar movement pattem, which they described as "...an eastward summer dispersal..." Figures 8a and $8 \mathrm{~b}$ shows seasonal locations of two male sage grouse. Both grouse were captured near the Range 10 lek. Their movement patterns are representative of the males monitored during 1991. Eberhardt and Hofmann (1991) expressed the belief that males made similar movements [into the Impact Area and Training Area 5B (called Training Arca $13 \mathrm{C}$ at that time)] as a means of avoiding troop-training activities. Training normally occurs on the YTC on gently sloping terrain in the valleys. Several studies of sage grouse have shown that sage grouse summer range has traditionally been in "upland meadows," 

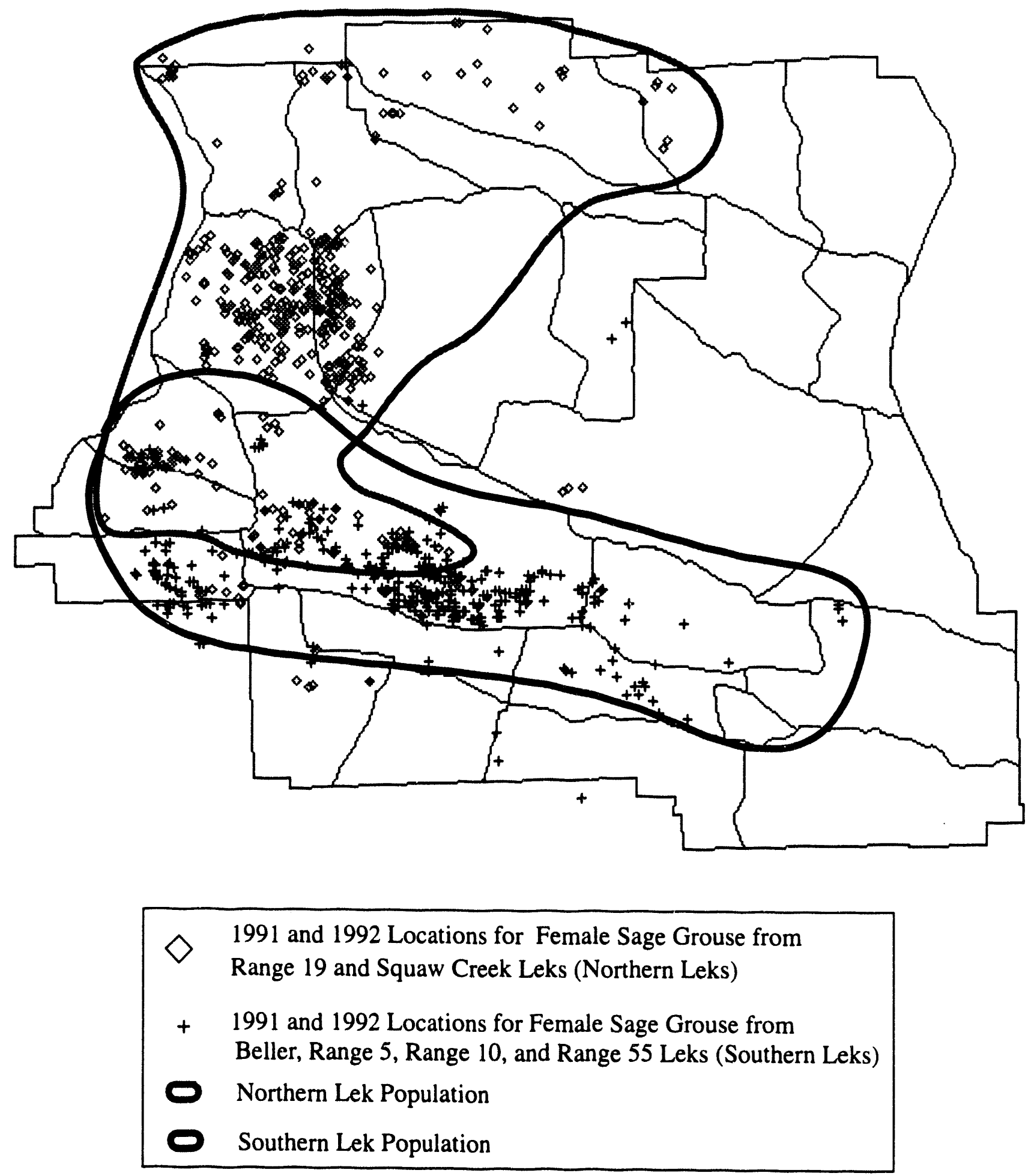

Figure 6. Sage Grouse Locations on the Yakima Training Center by Geographic Region as Distinguished by Northern and Southem Leks 


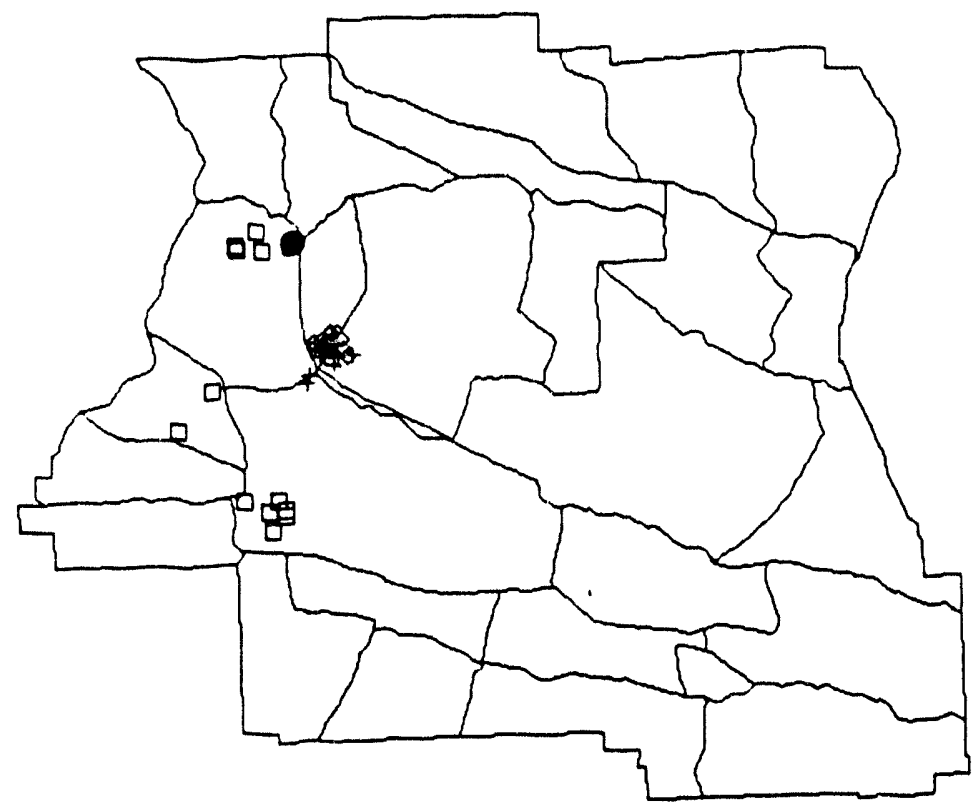

a) 1991 Locations for Grouse 9207

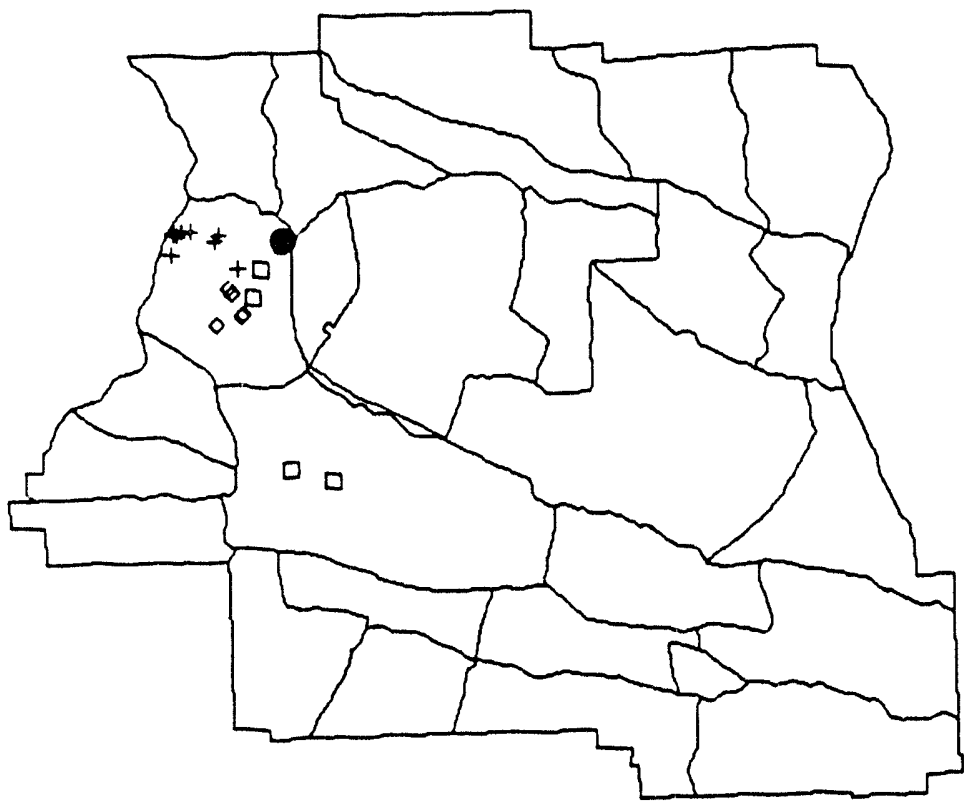

b) 1992 Locations for Grouse 8325

\begin{tabular}{|lll|}
\hline+ & Spring & Range 19 Lek \\
$\diamond$ & Summer & \\
$\square$ & Fall & \\
\hline
\end{tabular}

Figure 7. Seasonal Land Use Patterns for Two Female Sage Grouse from Range 19 Lek 


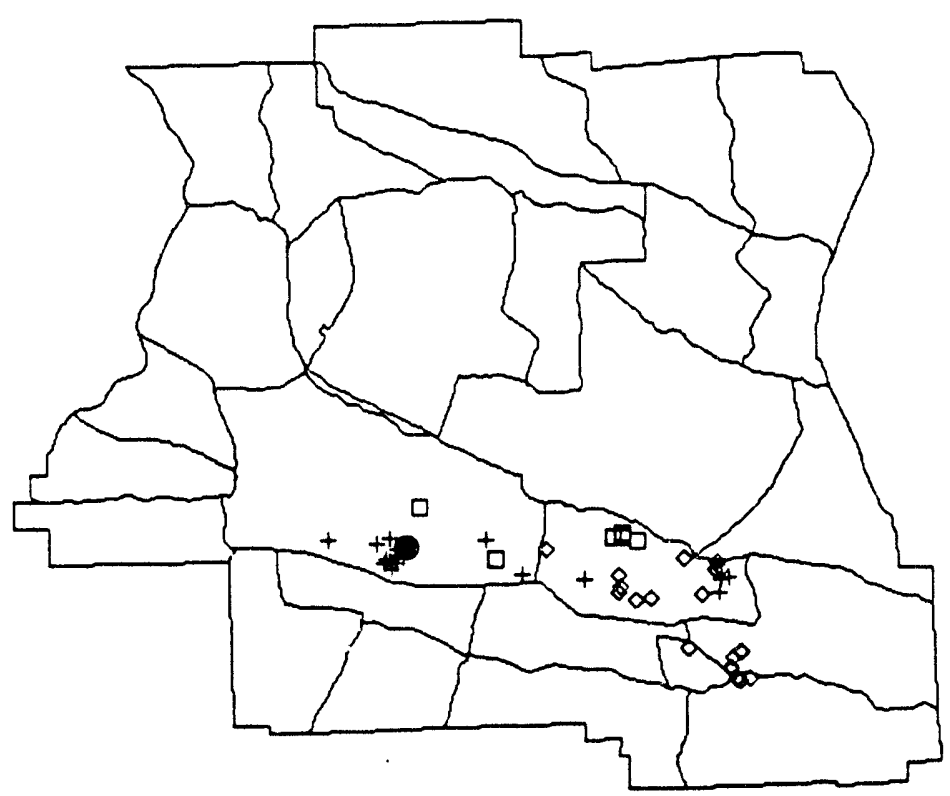

a) Grouse 8240

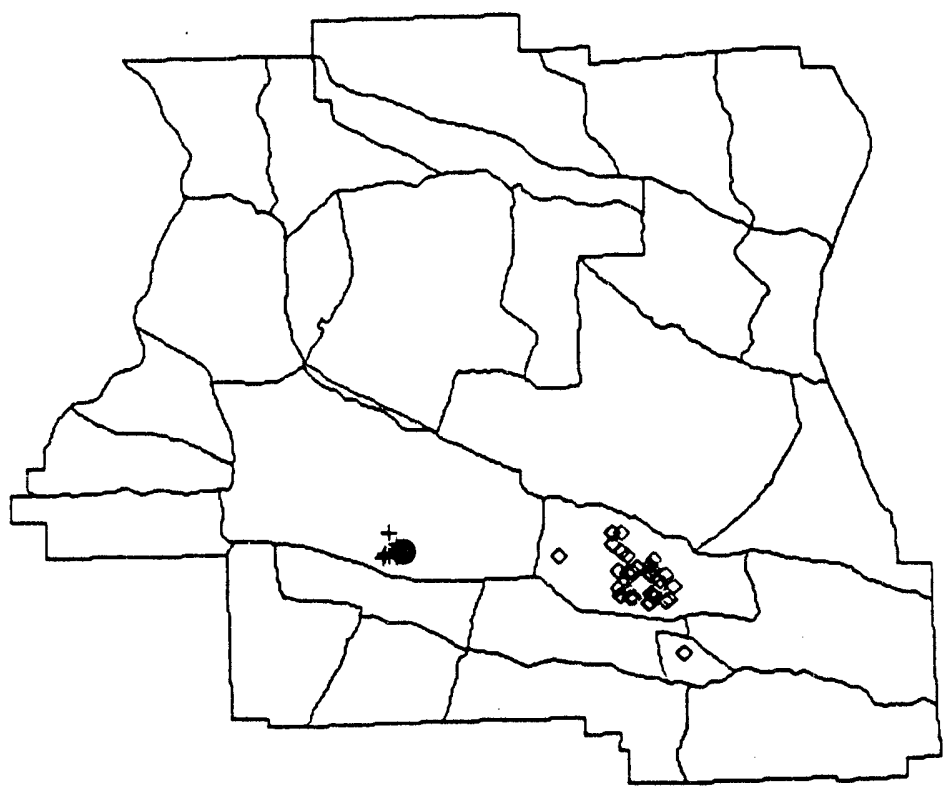

b) Grouse 8260

\begin{tabular}{|lll|}
\hline+ & Spring \\
$\diamond$ & Summer \\
$\square$ & Fall
\end{tabular}

Figure 8. 1991 Seasonal Land Use Patterns for Two Male Sage Grouse from Range 10 Lek 
"sagebrush and bottom land habitats," "moist creek bottoms," and "river meadows," (Oakleaf 1971; Hayden-Wing et al. 1986; Schoenberg 1982), although much more has been written on the use of these habitats by hens with broods than by males. Reports made in the literature (Call and Maser 1985; Klebenow 1969) indicate that sage grouse move up elevation gradients in the summer to seek succulent vegetation. It seems equally possible that movements by male sage grouse from leks in the valleys to higher elevations may be as much an expression of habitat preference as a response to disturbances caused by troop training. (Specific analyses of use of slope and elevation by sage grouse on the YTC are presented in following sections). One monitored male from the Beller lek spent a considerable portion of the summer on Umtanum Ridge near the southem boundary of the Impact Area and the northem boundary of Training Area 7, which is used more extensively for training than Training Area 5B. For a comparison of dispersal distances for male versus female sage grouse from leks in 1991 see Appendix C.

\section{Distance and Distribution of Nests from Leks}

Summary data for distance measurements from leks to nests are shown in Table 3. The combined data include 5 nest locations from 1990 (Eberhardt and Hofmann 1991), 9 from 1991, and 35 from 1992. The average lek-to-nest distance ranged from $3.9 \mathrm{~km}$ for the Range 5 lck to $6.8 \mathrm{~km}$ for the Squaw Creek East lek. Squaw Creek East is a new (1991) lek and is located approximately $1.3 \mathrm{~km}$ SE of the large Range 19 lek. The minimum distance of any known nest to the lek was $0.4 \mathrm{~km}$, and the maximum distance was $19.4 \mathrm{~km}$.

The distribution of nest-to-lek distances was not normally distributed. For five of the six active leks, the median distance was smaller than the mean (one lek had only two nests, and thus median and mean values were equal), indicating that a few birds from each lek traveled relatively long distances to nest. Figure 9 plots all known sage grouse nests from 1990, 1991, and 1992. Three nest sites from unmarked hens are shown in addition to the 49 nests for which lek association were known. Also shown in Figure 9 are circular "buffer" zones for each lek having a radius equal to the median lekto-nest distance. For each lek, 50\% of the nests lie outside of the zone and $50 \%$ inside. When viewed collectively, only seven of 52 nests lie outside of any buffer zone. Thus, the dispersal of hens to

Table 3. Distances of 1990 to 1992 Sage Grouse Nests from Leks for Yakima Training Center

\begin{tabular}{|c|c|c|c|c|c|c|}
\hline & \multicolumn{6}{|c|}{ Distance $(\mathrm{km})$ of Nests from Leks } \\
\hline & Range 5 & Range 10 & Range 19 & Range 55 & Beller & Squaw \\
\hline Average dislance & 3.93 & 5.16 & 4.96 & 5.28 & 6.58 & 6.79 \\
\hline Standard deviation & 1.38 & 4.93 & 4.28 & & 6.59 & 5.62 \\
\hline $95 \%$ interval(a) & 1.35 & 4.32 & 1.65 & & 5.27 & 4.50 \\
\hline Minimum & 2.52 & 0.51 & 0.44 & 4.26 & 0.84 & 1.77 \\
\hline Maximum & 5.76 & 12.08 & 14.82 & 6.30 & 19.39 & 13.92 \\
\hline Median & 3.72 & 3.45 & 2.94 & 5.28 & 5.55 & 4.76 \\
\hline Number of nests & 4 & 5 & 26 & 2 & 6 & 6 \\
\hline
\end{tabular}

(a) $95 \%$ confidence interval $=$ average $\pm 95 \%$ interval. 


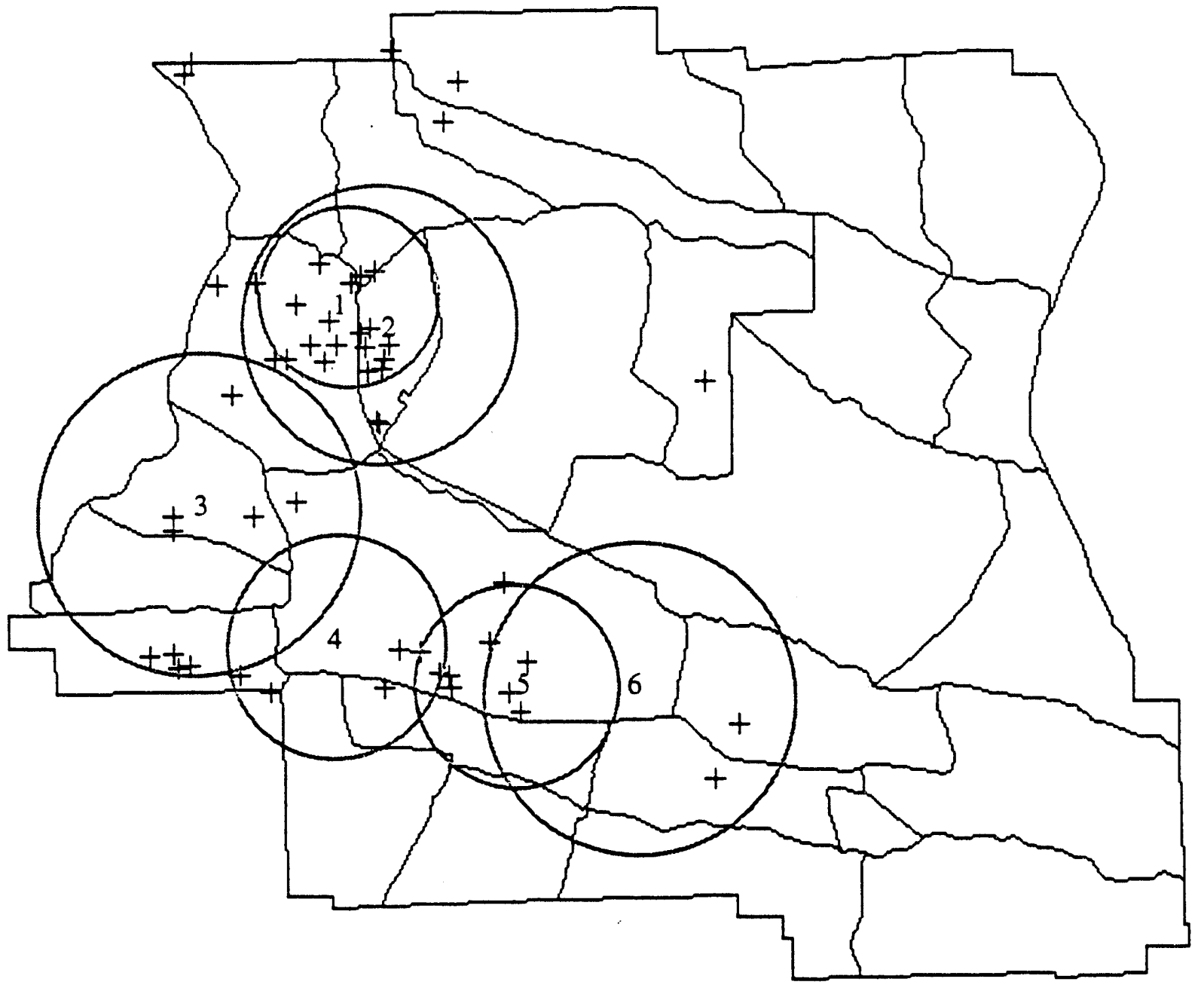

\begin{tabular}{|llcl|}
\hline 1 & Range 19 Lek & + & Sage Grouse Nests \\
2 & Squaw Creek Lek & 0 & Median Lek-To-Nest Distance \\
3 & Beller Lek & & \\
4 & Range 5 Lek & & \\
5 & Range 10 Lek & & \\
6 & Range 55 Lek & & \\
\hline
\end{tabular}

Figure 9. Buffer Zones Centered on Leks for 1990, 1991, and 1992 Sage Grouse Nest Locations 
nesting sites results in a number of birds originating from one lek nesting in the "vicinity" of other nearby leks. Schroeder(a) noted that sage grouse studied in Douglas County during 1992 also moved to nesting areas near a lek other than the one used. The "overlap" of nesting areas by lek suggests that preferred nesting habitat is not uniformly available adjacent to all leks. Within each geographical area (Figure 6), female sage grouse from separate leks sometimes share common nesting areas.

Because preferred nesting areas appear to be reasonably well contained within the buffer areas, we suggest that these buffer zones provide a sound basis for identifying areas where maintenancelevel management of sage grouse on the YTC can be most effectively practiced. These areas can be considered "core" areas of primary importance for sage grouse management on the YTC. Actionis that should be considered include protection of nesting area from disturbance during the nesting season, protection of high-quality nesting habitat from fire and mechanical disturbance, and restoration of marginal habitat (perhaps through sagebrush plantings). Eberhardt and Hofmann (1991) identified spring (nesting season) sage grouse habitat on the YTC; additionally, they mapped locations where sagebrush is capable of growing, but is currently absent.

\section{Habitat Use by Sage Grouse}

\section{Slope as Element of Habitat Selection by YTC Sage Grouse}

Sage grouse locations for 1991 and 1992 were analyzed using GRASS. The 1991 data included approximately equal numbers of male and female grouse, whereas in 1992, only female grouse were monitored. The expected number of grouse locations by slope was determined by multiplying the total number of grouse location observations times the proportion of the YTC land area covered by each $5^{\circ}$ category into which slope was divided. Slope was divided into six categories beginning at zero and incremented by $5^{\circ}$ up to $25^{\circ}$, with an additional final category including all areas having greater than $25^{\circ}$ slope.

Female sage grouse on the YTC showed a highly significant deviation from the expected use of slope based on its availability (Table 4), except for summer 1992. Slopes in the 0 to $5^{\circ}$ category were preferred by female sage grouse in all seasons. Even in summer 1992, where the total distribution of female grouse locations by slope did not show a significant deviation from expected, the number of locations in the 0 to $5^{\circ}$ class was significantly greater than expected $\left(X^{2}=4.7,1 \mathrm{df}, \mathrm{p}=<0.05\right)$. Distributions of locations for male sage grouse (male grouse data for 1991 only) were significant during spring and summer, but not in fall (Table 4). Male sage grouse preferred 0 to $5^{\circ}$ slopes in the spring, but shifted their preference to 6 to $10^{\circ}$ slopes in the summer (Table 4). No slope preference was shown for fall, but relatively few observations were made, and the male sage grouse at that time had begun their meandering movements back toward the lcks.

Not surprisingly, nest sites (52 nest locations combined for 1990-1992) showed a significant trend to be positioned on slopes of 0 to $5^{\circ}$. Limited data ( 36 observations) on females with broods in 1992 failed to show a pattern of use similar to that for lone birds and for nest sites $\left(x^{2}=-4.3,5 \mathrm{df}\right.$, $\mathrm{p}>0.5$ ). Because nests were located on 0 to $5^{\circ}$ slopes, but hens with broods showed no slope preference, we conclude that some hens moved up slope with their broods. This observation lends credence

(a) Mike Schroeder, Washington State Department of Wildlife, personal communication, October 1993. 
Table 4. Slope Preferences of Sage Grouse for 1991 and 1992

\begin{tabular}{|c|c|c|c|c|}
\hline & & Spring & & \\
\hline Slope $\left({ }^{\circ}\right)$ & $\begin{array}{c}\text { Female(a) }^{(a)} \\
1991 \\
\end{array}$ & $\begin{array}{c}\text { Female } \\
1992 \\
\end{array}$ & $\begin{array}{l}\text { Male } \\
1991 \\
\end{array}$ & $\begin{array}{c}\text { Nests } \\
1990-2\end{array}$ \\
\hline$\overline{0-5}$ & + & + & + & + \\
\hline $6-10$ & 0 & - & 0 & 0 \\
\hline $11-15$ & - & - & - & - \\
\hline $16-20$ & - & - & - & - \\
\hline $21-25$ & - & - & - & - \\
\hline$>25$ & 0 & - & - & 0 \\
\hline
\end{tabular}

\begin{tabular}{|c|c|c|c|}
\hline & & Summe & \\
\hline Slope $\left({ }^{\circ}\right)$ & $\begin{array}{c}\text { Female } \\
1991\end{array}$ & $\begin{array}{c}\text { Female } \\
1992 \\
\end{array}$ & $\begin{array}{l}\text { Male } \\
1991\end{array}$ \\
\hline $0-5$ & + & ns & - \\
\hline $6-10$ & - & ns & + \\
\hline $11-15$ & - & ns & 0 \\
\hline $16-20$ & - & ns & - \\
\hline $21-25$ & - & ns & - \\
\hline$>25$ & - & ns & - \\
\hline
\end{tabular}

Fall

\begin{tabular}{lccc}
\hline & Female & Female & Male \\
Slope ( $)$ & 1991 & $\frac{1992}{1991}$ \\
$0-5$ & + & - & $\frac{1991}{n s}$ \\
$6-10$ & - & - & ns \\
$11-15$ & 0 & - & ns \\
$16-20$ & - & - & ns \\
$21-25$ & - & - & ns \\
$>25$ & 0 & - & ns
\end{tabular}

(a) $+=$ prefer, $-=$ avoid, $0=$ no preference [significant chi-square test $(p<0.05)$ ], ns $=$ not significant $[$ chi-square $(p>0.05)]$.

to the observation of Call and Maser (1985) that hens migrate up slope seeking habitats with succulent forbs as plants at lower elevations mature and dry. An alternative explanation may be that hens on the YTC move their broods up slope to escape human activity associated with troop training.

\section{Elevation as an Element of Habitat Selection by Sage Grouse}

In a manner similar to that for slope, we evaluated individual grouse locations relative to land area within elevation bands on the YTC. We used $100-\mathrm{m}$ increments of elevation between $100 \mathrm{~m}$ and $1000 \mathrm{~m}$, with an additional band including all areas above $1000 \mathrm{~m}$ (maximum elevation $1280 \mathrm{~m}$ ), which encompasses all elevations on the YTC. Table 5 shows sage grouse preferences for elevation zones on the YTC.

Female sage grouse showed a distinct pattern (significant chi-square, $p<0.05$ ) to their elevation use during all seasons for both 1991 and 1992. During the spring the females preferred the 600 to 
Table 5. Elevation Preferences of Sage Grouse for 1991 and 1992

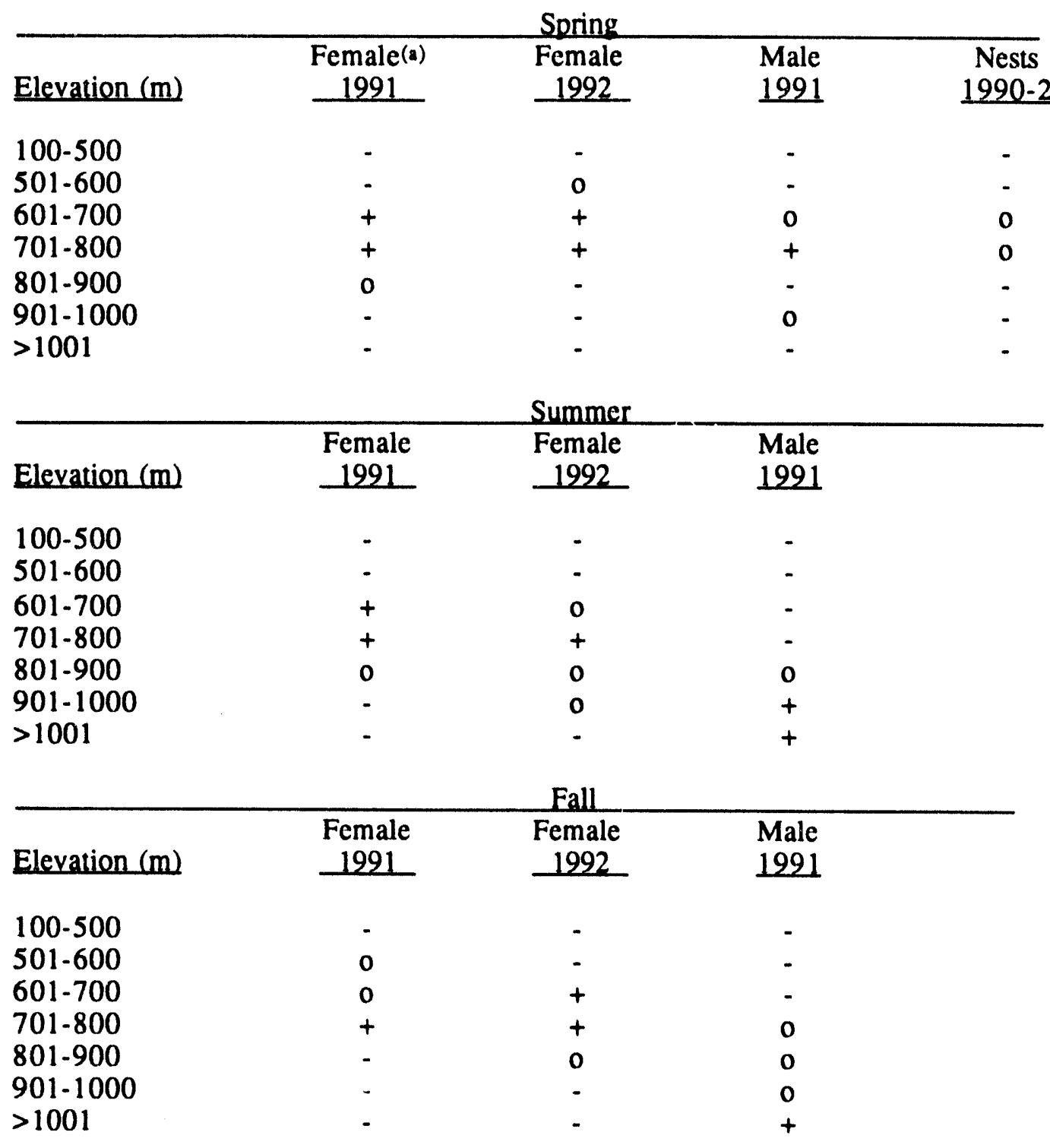

(a) $+=$ prefer, $-=$ avoid, $0=$ no preference [significant chi-square test $(p<0.05)$ ], ns $=$ not significant $[$ chi-square $(p>0.05)]$.

800 -m elevation band. In summer 1992, females moved to slightly higher ground (700 to $800 \mathrm{~m}$ ). Although there was not a significant deviation in elevation from expected for all elevations combined for females in 1992, the individual test at the 700 - to 800 -m elevation was significant $\left(X^{2}=45.9\right.$, $\mathrm{p}<0.005$ ). During the fall, females moved back to approximately the same elevations as they used in the spring.

Male sage grouse selected for elevation during spring, summer, and fall. Of 256 total observations on male grouse in 1991, only once was a bird observed below $500 \mathrm{~m}$ and seldom (seven times) above $1000 \mathrm{~m}$. Chi-square tests for all seasons, during both years, were significant $(p<0.05)$, 
suggesting that grouse did not simply use elevation according to its availability. Males generally preferred elevations between 700 and $800 \mathrm{~m}$ in the spring but moved up approximately $200 \mathrm{~m}$ (900 to $1000 \mathrm{~m}$ ) for the summer. Fall location data for males were few and highly variable during the time when the birds were meandering and beginning a gradual movement back toward the leks. However, the few observations on males showed them to be at the highest elevations (1000 to $1100 \mathrm{~m}$ ) during the fall. The greatest distinction between use of elevations by male and female sage grouse appears to be a separation during summer and fall, when males make use of higher terrain.

For all years combined, nests occurred almost exclusively (45 of 52 nests) at elevations between $600 \mathrm{~m}$ and $800 \mathrm{~m}$. The remaining nests were immediately above and just below the $600-$ to $800-\mathrm{m}$ range. Hens with broods were observed at elevations ranging from 600 to $1000 \mathrm{~m}$. One third of the 1992 hens-with-broods sitings were above $800 \mathrm{~m}$; whereas, none of the nests (all four years) were above $800 \mathrm{~m}$. This observation of an upward migration of hens with broods corresponds well with the inference previously made from analysis of slope use by female sage grouse, because many of the higher elevations on the YTC are upslope from bottom lands birds used during the spring.

\section{Slope Aspect as an Element of Habitat Selection by YTC Sage Grouse}

Compass bearings were divided into eight equal $45^{\circ}$ sectors. For each sector, the proportion of YTC lands occupying that sector was determine using GRASS. An expected distribution for sage grouse locations by aspect was then calculated as the fraction of total YTC land area facing each $45^{\circ}$ sector times the total number of sage grouse location observations for the time or scason under consideration.

Chi-square tests were then used to evaluate whether the distribution of grouse locations was in proportion to the availability of slopes having those aspects. Table 6 shows aspect preference by sage grouse during 1991 and 1992. Sage grouse showed a clear preference for north- and west-facing slopes and avoided south and southeast-facing slopes during spring and summer of both years and during fall 1991. In fall 1991, however, only males showed a significant preference for southwestfacing slopes.

\section{Proximity to Water}

We used GRASS to analyze 1991 and 1992 sage grouse location data relative to potential water sources. Comparison of sage grouse location data for spring through fall of each year with the distribution of springs on the YTC clearly showed that sage grouse most intensively occupied areas that were remote from springs. This result is not surprising because sage grouse were found on low to moderate slopes and at lower elevations. Springs on the YTC, however, are found near the headwaters of small drainages along Yakima Ridge, Umtanum Ridge, and the Saddle Mountains (84\% of the springs are on slopes greater than $5^{\circ}$, and $48 \%$ are at elevations greater than $800 \mathrm{~m}$ ). Many springs on the YTC have been developed for livestock watering. We did not visit springs to determine whether they provide wet meadow conditions that sage grouse elsewhere have been reported to seek (Call and Maser 1985; Klebenow 1969) when vegetation elsewhere dries up.

Additional analyses were conducted using GRASS to determine whether sage grouse were attracted to major streams that are known to flow most or all of the year (3rd, 4th, and 5th order streams). We expected that this analysis would best reveal any preference by sage grouse for either free water or for succulent riparian vegetation. We assumed that grouse would be found more frequently within a $1-\mathrm{km}$ band on either side of streams than at greater distances, if indeed the grouse 
Table 6. Slope Aspect Preferences of Sage Grouse for 1991 and 1992

\begin{tabular}{|c|c|c|c|c|}
\hline Aspect & $\begin{array}{c}\text { Female(a) }^{(1991} \\
\end{array}$ & $\begin{array}{l}\text { Spring } \\
\text { Female } \\
1992 \\
\end{array}$ & $\begin{array}{l}\text { Male } \\
1991\end{array}$ & $\begin{array}{c}\text { Nests } \\
1990-9\end{array}$ \\
\hline West & 0 & + & 0 & ns \\
\hline Southwest & 0 & - & + & ns \\
\hline South & 0 & - & 0 & ns \\
\hline Southeast & - & - & - & ns \\
\hline East & 0 & 0 & - & ns \\
\hline Northeast & 0 & 0 & 0 & ns \\
\hline North & + & + & 0 & ns \\
\hline Northwest & 0 & 0 & 0 & ns \\
\hline
\end{tabular}

\begin{tabular}{lccc}
\multicolumn{1}{c}{ Aspect } & $\begin{array}{c}\text { Female } \\
1991\end{array}$ & $\begin{array}{c}\text { Female } \\
1992\end{array}$ & $\begin{array}{c}\text { Male } \\
1991\end{array}$ \\
\cline { 2 - 3 } West & & & \\
Southwest & 0 & 0 & 0 \\
South & 0 & 0 & 0 \\
Southeast & 0 & 0 & 0 \\
East & 0 & 0 & 0 \\
Northeast & 0 & 0 & 0 \\
North & + & 0 & - \\
Northwest & - & + & 0 \\
& & 0 & 0
\end{tabular}

\begin{tabular}{lccc} 
& \multicolumn{3}{c}{ Fall } \\
\cline { 1 - 1 } \multicolumn{1}{c}{ Aspect } & Female & Female & Male \\
West & 1991 & 1992 & 1991 \\
\cline { 2 - 3 } Southwest & & & \\
South & ns & 0 & 0 \\
Southeast & ns & 0 & + \\
East & ns & 0 & 0 \\
Northeast & ns & - & 0 \\
North & ns & 0 & - \\
Northwest & ns & 0 & 0 \\
& ns & 0 & 0 \\
& ns & - & -
\end{tabular}

(a) $+=$ prefer, $-=$ avoid, $0=$ no preference [significant chi-square test $(p<0.05)$ ], ns $=$ not significant $[$ chi-square $(p>0.05)]$.

were using steams for free water. We further speculated that grouse might be most attracted to streamside habitat during summer when temperatures are greatest and when lowland vegetation away from streams is largely desiccated in this climate of warm, dry summers. Separate analyses were conducted by season for 1991 and 1992 (Table 7). 
Table 7. Chi-Square Values for Distribution of Sage Grouse Locations Within and Beyond $1 \mathrm{~km}$ from Major Streams on the Yakima Training Center. (Significant values indicate more observations within $1 \mathrm{~km}$ of water than expected.)

\begin{tabular}{lllccc} 
Year & Sex & Season & Chi-square & df & D \\
\hline 1991 & & Spring & 0.11 & 1 & 0.75 \\
& $M$ & Summer & 2.07 & 1 & 0.16 \\
& M & Fall & 2.06 & 1 & 0.16 \\
& F & Spring & 0.11 & 1 & 0.75 \\
& F & Summer & 7.23 & 1 & 0.008 \\
1992 & F & Fall & 11.14 & 1 & $<0.005($ a) \\
& F & Spring & 14.59 & 1 & $<0.005($ a) \\
& F & Summer & 0.02 & 1 & 0.89 \\
& F & Fall & 7.36 & 1 & $<0.01($ (a)
\end{tabular}

(a) Significant chi-squares for females in summer and fall 1991 and spring and fall 1992.

Possibly, the location of streams coinciding with the low elevation and low slope areas on the YTC may result in an apparent "stream-side" habitat preference when other factors are actually influencing grouse distribution.

The literature is divided on the use of free water by sage grouse. Wallestad (1975) tracked broods in central Montana and reported no movements, suggesting a use of iree water in early summer. In late summer, even though broods had moved to areas of succulent vegetation, he observed no use of free water by the grouse. Call and Maser (1985) provided a review of literature on the use of permanent water sources by sage grouse. Their summary statement expressed the belief that sage grouse may not require free water as long as they have access to succulent vegetation.

\section{Use of Soil Types (Grouped)}

We used a soils map of the YTC that was digitized from a U.S. Soil Conservation Service map by Eberhardt and Hofmann (1991). In general the two soil groups (Benway-Selah-Brehm and Vantage-Ralock-Clerf) that lie at mid-elevations between Yakima and Umtanum ridges were preferred by female grouse in spring 1991 and spring and summer 1992 (Table 8). Those soils are characterized by being generally loamy and subject to intermediate amounts (9 to 12 in.) of precipitation. They are also capable of supporting a big sagebrush/bunchgrass plant community. Male grouse, because they spent much of the spring breeding season in the same areas with female grouse, were also associated with Benway-Selah-Brehm soils in 1991. However, the summer and fall areas containing Camaspatch-Whiskeydick-Wockum soils were preferred by males. Those soils lie at higher elevations and receive more precipitation (12 to $15 \mathrm{in}$.). We do not view soils per se as a factor selected by sage grouse, but simply as another way to view the general habitat requirements of sage grouse. Those variables that we identify as climate related, together with topography (slope, elevation, and aspect) combine with substrate to produce soils. The combination of climate and soils influence climax vegetation types. 
Table 8. Preferences of Sage Grouse for Soils

\section{Soils}

Malaga-Starbuck

Wanapum-Drysel-Scoon

Benway-Selah-Brehm

Fortyday-Disage-Sohappy

Vantage-Ralock-Clerf

Camaspatch-Whiskeydick-

Wockum
Soils

Malaga-Starbuck

Wanapum-Drysel-Scoon

Benway-Selah-Brehm

Fortyday-Disage-Sohappy

Vantage-Ralock-Clerf

Camaspatch-Whiskeydick-

Wockum

Soils

Malaga-Starbuck

Wanapum-Drysel-Scoon

Benway-Selah-Brehm

Fortyday-Disage-Sohappy

Vantage-Ralock-Clerf

Camaspatch-Whiskeydick-

Wockum

\begin{tabular}{ccccc}
\multicolumn{5}{c}{ Spring } \\
\hline & Female(a) & Female & Male & Nests \\
Precip_(in) & 1991 & 1992 & 1991 & $1990-2$ \\
\hline
\end{tabular}

6-9

6-9

9-12

6-9

9.12

$12-15$

$\begin{array}{lll}- & - & 0 \\ + & - & - \\ + & + & 0 \\ + & - & - \\ + & - & 0\end{array}$

Summer

\begin{tabular}{lccc}
\hline & Female & Female & Male \\
Precip_(in.) & 1991 & 1992 & 1991
\end{tabular}

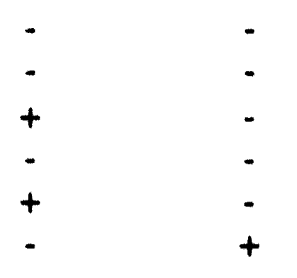

Fall

\begin{tabular}{llcl}
\hline & Female & Female & Male \\
Precip_(in.) & 1991 & 1992 & 1991 \\
\hline
\end{tabular}

$\begin{array}{cccc}6.9 & 0 & - & 0 \\ 6-9 & - & - & 0 \\ 9-12 & + & + & 0 \\ 6-9 & - & - & - \\ 9-12 & 0 & 0 & - \\ 12-15 & - & - & +\end{array}$

(a) $+=$ prefer, $-=$ avoid, $0=$ no preference [significant chi-square test $($ alpha<0.05)], ns = not significant [chi-square (alpha $>0.05)$ ].

\section{Vegetation Types in Sage Grouse Use Areas}

During 1992, vegetation types were recorded for specific locations for each of the 538 grouse observations. Vegetation associations included big sage/bluebunch wheatgrass, bluebunch wheatgrass/Poa sandbergii, degraded big sage/bluebunch wheatgrass, big sage/Poa sandbergii, and riparian. Seventy-nine percent (424 observations) of all observations were in big sage/bluebunch 
wheatgrass areas. Fourteen percent were bluebunch wheatgrass/Poa grassland, and $4 \%$ were in degraded big sage/blucbunch wheatgrass. Approximately $1 \%$ was in each of the remaining three vegetation associations.

Sage grouse clearly preferred the big sage/bluebunch grass association. To fully evaluate habitat quality and identify sage grouse use of various stages of habitat degradation, stages of habitat degradation need to be identified and use of those habitats by sage grouse evaluated. In this study, many of the big sage/bluebunch wheatgrass sites where sage grouse were observed had obviously been modified by past troop training activity. We have no information on the degree of degradation within preferred habitat that is "acceptable" to sage grouse.

\section{Sage Grouse Use of Grazing Areas}

- We reviewed the distribution of sage grouse on the YTC in 1991 and 1992 relative to grazing unit boundaries. Figures $10 \mathrm{a}$ and $10 \mathrm{~b}$ show total sage grouse locations for radio-marked sage grouse in 1991 (both sexes) and 1992 (females only), respectively. Grazing units A and B were lightly used by sage grouse except for a concentration of 1991 observations for male grouse in the northern portion of grazing Units B and $C$ near their juncture. The area includes the higher elevations south of Umtanum Ridge near the divide separating the Cold Creek and Selah Creek drainages. This area is a favored summering area for male grouse (see the earlier section on male grouse movements and also Eberhardt and Hofmann (1991)]. Virtually no female grouse were located in Grazing Unit $C$ in 1992, and few grouse were observed either year in Unit D. Grazing units $E$ and $F$ both had numerous sage grouse siting locations in 1991 and 1992. In summary, those portions of grazing Units A, B, and $C$ lying south of Yakima Ridge and all of Grazing Unit $D$ were lightly used by sage grouse. The remaining portions of Units $A, B, C$, and much of $E$ and $F$ were used more intensively by sage grouse. No attempt was made in this study to evaluate sage grouse habitat within grazing units as it might have been impacted by grazing. Thus, we cannot relate sage grouse use of grazing areas to grazing impacts.

\section{Response to Training Activity}

Disturbance of sage grouse is inevitable when foot soldiers or vehicles involved in training activities encounter the birds, whether on leks, at nest sites, or within the birds' general feeding, loafing, or roosting areas. Studies conducted in 1991 to identify behavioral response by sage grouse to training activities were twofold: first, we observed leks to record grouse response to area training activity, and second, we analyzed radio-collared grouse movements during and immediately after localized training.

The 1991 lek observations were made before the Sage Grouse Conservation Agreement was signed, and thus, specific restrictions on firing in the vicinity of leks during times of day when grouse are expected to be in attendance and limits on training near leks during the breeding season had not yet been established. Lek observations in 1991 failed to document any response because no training activity was observed near the leks.

Evaluation of troop-training activity on sage grouse behavior also involved comparing distances that radio-collared birds moved daily during a period of intensive troop training with distances that 


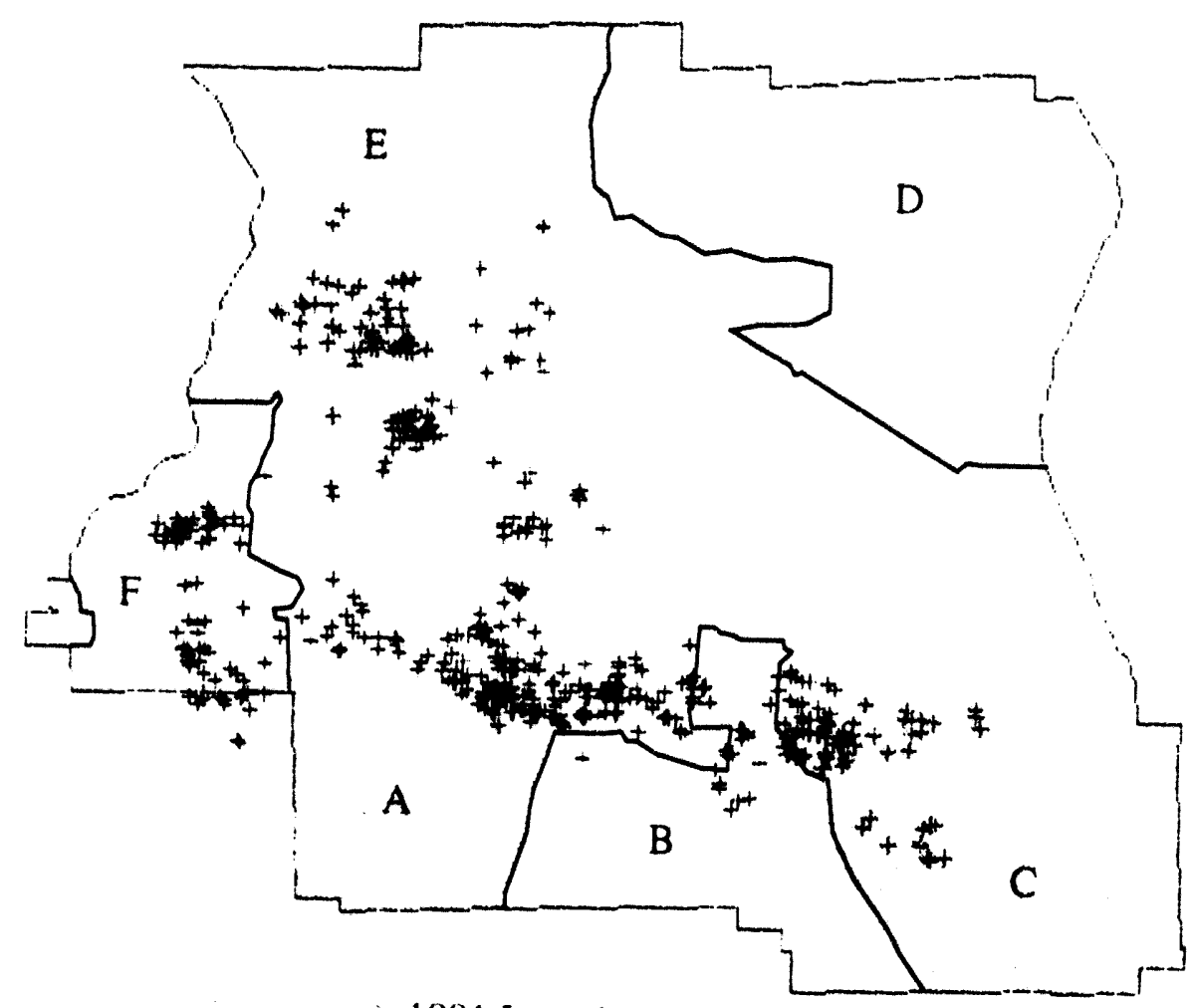

a) 1991 Locations

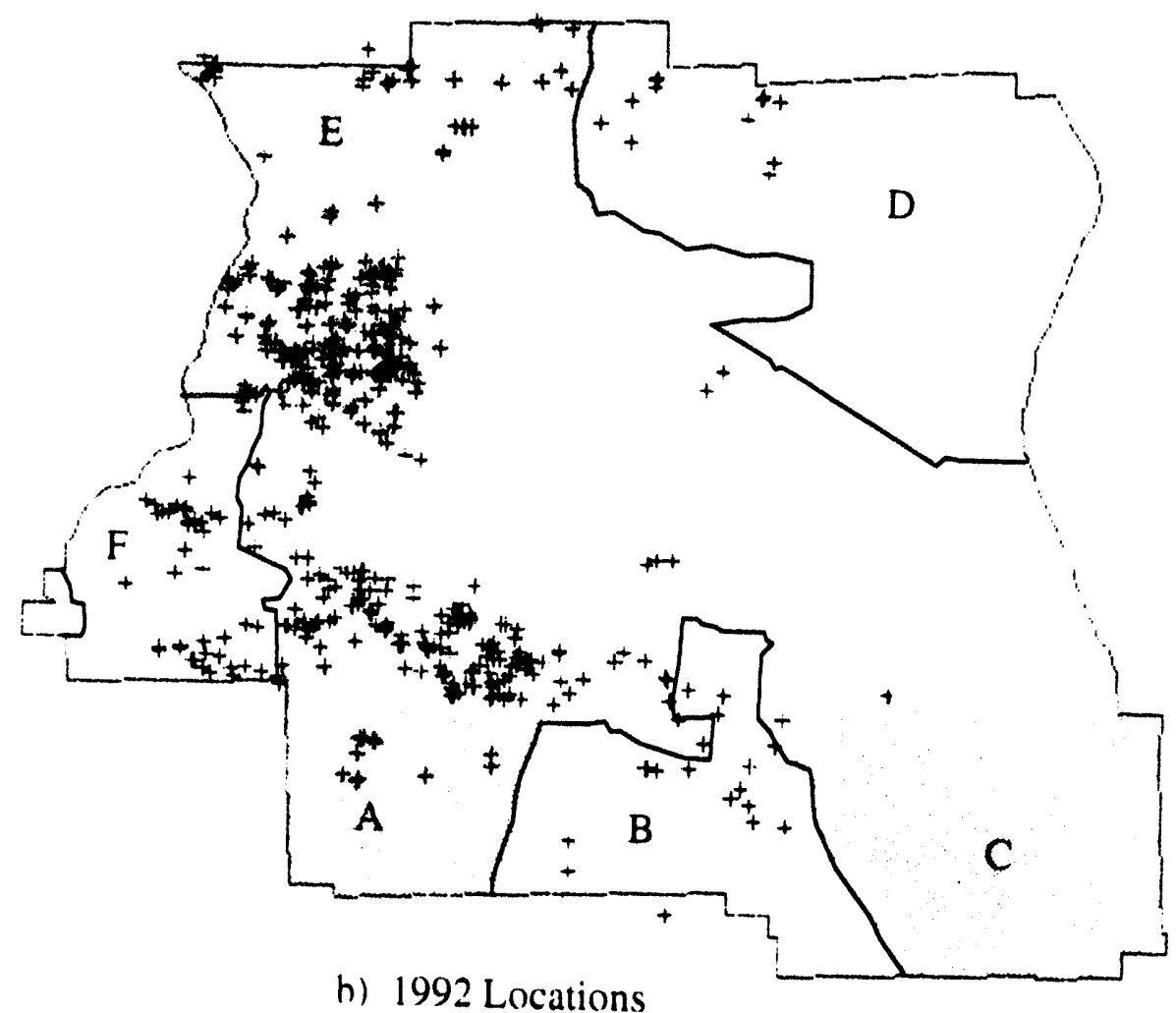

Figure 10. Sage Grouse Locations Relative to Grazing Units 
those same birds moved after troops left the training areas. Daily monitoring of grouse was conducted during a 2 1/2-week-period in June 1991. National Guard troop training activity on June 10, 1991, through June 21, 1991, occurred in proximity to nine monitored sage grouse. Six of those nine birds showed greater distances between daily relocation positions during the period of troop training than for the period immediately following training. The mean distance moved per day by birds during training was $1031 \mathrm{~m}$ compared with $832 \mathrm{~m} /$ day immediately after training. The power of the one-tailed (we hypothesized that troop training activities would lead to greater bird movement) paired t-test was low because of the small sample size. The test statistic was very close to, but not at, a level $(p=0.05)$ indicating a significantly greater movement distance by birds in the presence of troop training $(t=1.629, \mathrm{df}=8, \mathrm{p}=0.071)$.

All nine of the monitored birds remained in the same general vicinity before, during, and immediately after troops occupied the training areas. Perhaps the most significant observation made was that none of the birds monitored reacted to the presence of troops by making large, erratic movements. The ecological interpretation of this observation may be that, for the level of training that occurred, the birds were not forced from the general area of their preferred habitat. Mike Schroeder(a) noted that female sage grouse in Douglas County, Washington, in 1992 remained within about 1 to $3 \mathrm{~km}$ of their nest sites even after the nesting period.

\section{Sage Grouse Use of Areas with Degraded Vegetation}

Satellite imagery has been used on the YTC to map vegetation/land cover and to identify areas where training activity has severely reduced vegetation (Stephan et al. 1990). We used vegetation degradation map scenes whose SPOT satellite image has at least 70\% bare soil (Stephan et al. 1990) to visually compare with maps of sage grouse use areas. We reasoned that removal of at least $70 \%$ of the vegetative cover would damage sagebrush to the point of reducing the land area to low quality sage grouse habitat. Two degradation map scenes were available for comparison with the 1991 and 1992 sage grouse location data. The 1991 degradation map was from September and the 1992 map from July.

When both the 1991 and 1992 sage grouse location data were compared with the respective annual degradation map, it became clear that few grouse occupied areas that showed a high density of pixels identified as degraded. Figures $11 \mathrm{a}$ and $11 \mathrm{~b}$ compare two maps, one showing the summer 1992 sage grouse locations and the second showing 1992 July degradation areas. Although the 1992 degradation map showed recovery, in that many of the 1991 degraded areas had become revegetated, it is clear that annual "recovery" cannot equate to restoration of sagebrush cover. More likely, it would include annual weeds or revegetated grass and forb cover. If sage grouse habitat improvement is to be practiced by restoring sagebrush on the YTC, specific candidate areas for restoration can be identified by annually creating a cumulative map of degradation areas and then selecting restoration sites from areas that are near sage grouse use/nesting areas and that have other features preferred by sage grouse (e.g., slope, slope aspect, elevation, and distance to known lek).

(a) Personal communication, Mike Schroeder, Productivity and Habitat Use of Sage Grouse in Northcentral Washington study project, Washington State Department of Wildlife. 


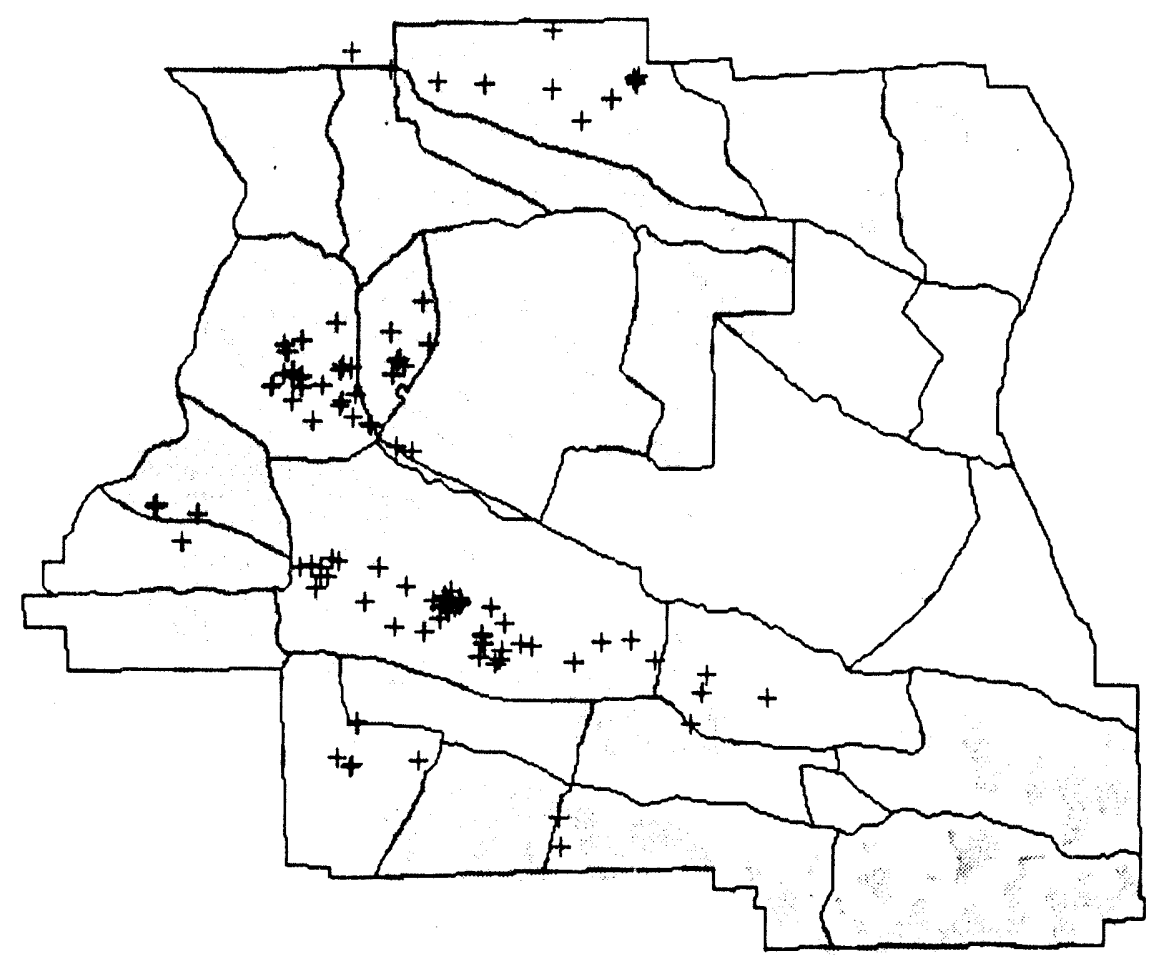

a) 1992 Sage Grouse Relocations in Relation to Summer Habitat

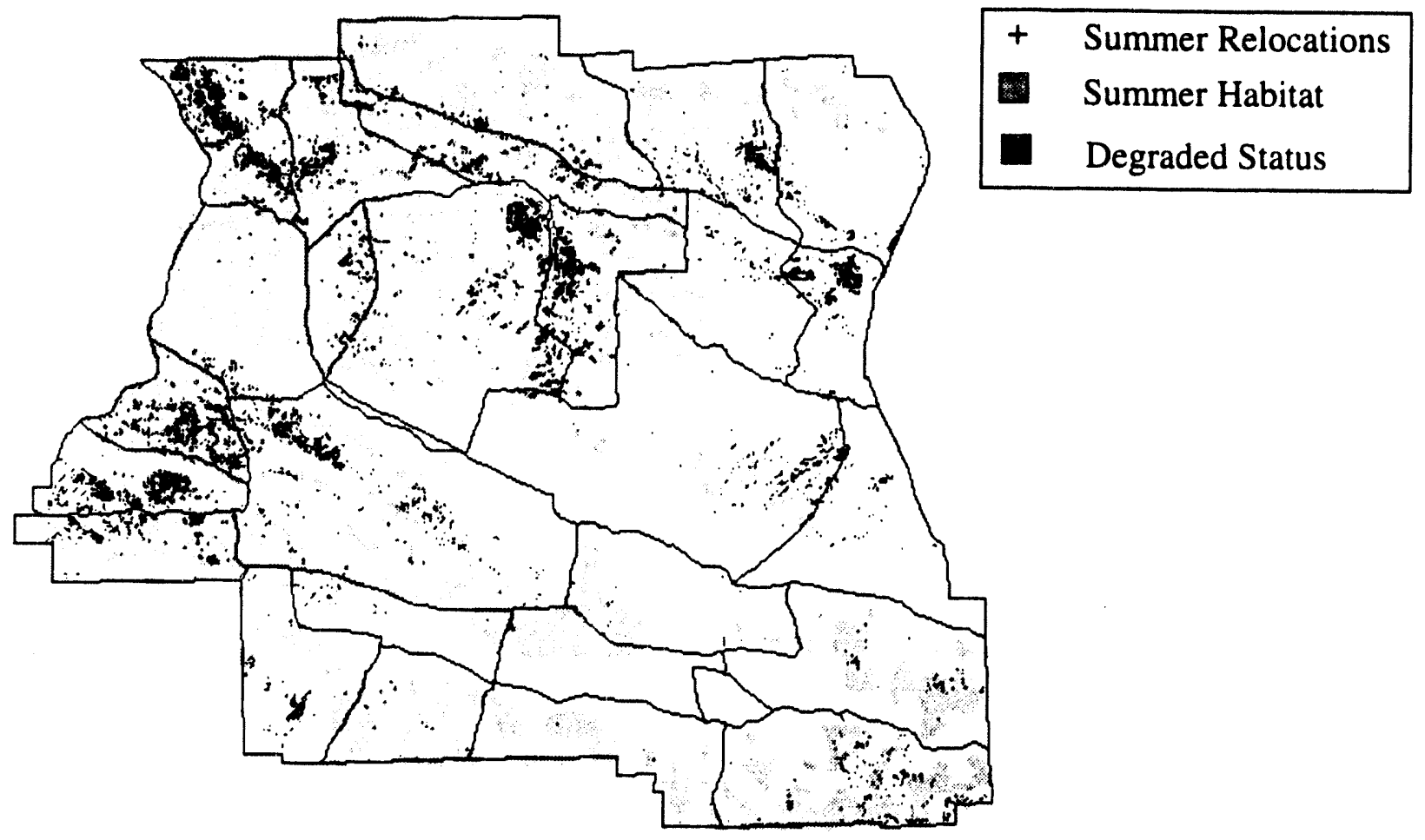

b) July 1992 Degredation Status in Relation to Summer Habitat

Figure 11. 1992 Sage Grouse Use on Summer Habitat and 1992 Degraded Areas Relative to Summer Habitat 


\section{Use of Knapweed Spray Areas}

Knapweed spray areas from 1987, 1988, 1989, and 1991 were examined relative to sage grouse location data for 1989 through 1992 . Because $90 \%$ of the knapweed spray areas lie within the general areas preferred by sage grouse, we compared sage grouse locations inside of spray areas with those outside spray areas, but within 0 to $5^{\circ}$ slopes and 600 - to $800-\mathrm{m}$ elevation bands. Chi-square analysis of knapweed spray areas (Table 9) indicates no detected deviation in the distribution of sage grouse relative to spray areas in 1988 or 1989 but significant differences in 1991 and 1992. There was an avoidance of 1991 spray area in 1991; however, birds did not avoid the 1989 spray area in 1989 so it is difficult to draw any cause and effect relationship. For example, the 1988 spray area was preferred in 1991 but avoided in 1992, while the 1989 spray area was avoided in 1992 but not before. Although significant chi-square test results existed for 1991 and 1992 sage grouse distribution data relative to spray areas, there seemed to be no logic or pattem to preferences (Table 9) displayed by the grouse.

Hoping to gain additional insight into the reasons that sage grouse may prefer or avoid spray areas, we examined data collected by Downs et al. (1994) relative to forb cover in several spray areas. They found that the 1991 spray area had less knapweed and fewer perennial forbs than the control area in 1991. However, their interpretation was limited by not having prespray plant sample data. Because sage grouse rely heavily on forbs in their diet, particularly in spring and summer, the avoidance of the 1991 spray area in 1991 seemed logical (birds avoiding an area with diminished food supply). However, the 1992 season had an even greater disparity between spray area and control area in cover for these two classes of forbs, yet there was no preference or avoidance of the 1991 spray area that year. We have no explanation for the preferences of knapweed spray areas by sage grouse shown in Table 9. Preferences could result from subtle differences in vegetation, annual weather patterns, disturbance factors related to troop training, or other causes.

Table 9. Chi-square Test Results for Sage Grouse Selection of Knapweed Spray Areas for 1989 to 1992

\begin{tabular}{|c|c|c|c|c|}
\hline Spray Area & 1989 & $\begin{array}{c}\text { Relocation } \\
1990 \\
\end{array}$ & 1991 & 1992 \\
\hline 1987 & ns & ns & $O(a)$ & 0 \\
\hline 1988 & ns & ns & + & - \\
\hline 1989 & ns & ns & 0 & - \\
\hline 1991 & ns & ns & - & 0 \\
\hline \# relocated & 18 & 3 & 39 & 19 \\
\hline Chi square & 8.297 & 5.278 & 67.349 & 31.227 \\
\hline d.f. & 4 & 4 & 4 & 4 \\
\hline Alpha & 0.085 & 0.264 & $<0.0005$ & $<0.0005$ \\
\hline
\end{tabular}

(a) $+=$ prefer, $-=$ avoid, $0=$ no preference [significant chi-square test $(p<0.05)$ ], ns $=$ not significant [chi-square $(p>0.05)$ ]. 


\section{Conclusions and Recommendations}

Sage grouse radio-telemetry relocation data were used in conjunction with GPS coordinates to identify grouse use areas in spring, summer, and fall 1991 and 1992 . Results of those analyses, using GRASS software and additional remote sensing data sets, led to a number of conclusions conceming the locations on the YTC most intensively used by sage grouse. The results also have allowed us to describe the birds' movement patterns and habitat preferences.

The following conclusions were derived from those analyses and additional observations:

- Lek counts of male sage grouse in 1991 and 1992 were similar to those in the previous several years.

- Population estimates during 1991 and 1992 based on lek counts suggest a population of 300 to 500 birds.

- Female sage grouse remained an average of $5 \mathrm{~km}$ from their respective leks in the spring and 6 to $7 \mathrm{~km}$ in the summer and fall.

- Male sage grouse moved directly from the lek areas to summer habitat that averaged $12 \mathrm{~km}$ from leks.

- The YTC sage grouse appear to consist of two subpopulations occupying distinct geographical areas. One area is in the broad, gently rolling plain lying north of Umtanum Ridge along the westem boundary of the YTC and the second is in the Selah Creek Valley between the Beller Drop Zone and Training Area 5B.

- Sage grouse hens positioned their nests an average of from 4 to $8 \mathrm{~km}$ from the leks they had attended.

- Buffer zones centered on the leks and at a distance of the median lek-to-nest distance for each lek contained most of the known nest sites (45 of 52).

- Female sage grouse displayed strong preference for 0 to $5^{\circ}$ slopes as did males during the spring. Males, however, occupied 6 to $10^{\circ}$ slopes in the summer.

- Female grouse preferred 600- to 800-m elevations in the spring, and tended to move up slope slightly ( 700 to $800 \mathrm{~m}$ ) in the summer and fall.

- Male sage grouse preferred to use habitat at higher elevations (900 to $1000+\mathrm{m}$ ) in the summer and fall.

- Sage grouse on the YTC did not frequent springs. Association of sage grouse with major streams at lower elevations was mixed and not clearly attributable to the use of streams for free water or to the use of succulent streamside vegetation for food.

- The vegetation association used extensively by sage grouse (79\% of the observations) was sagebrush/bluebunch wheatgrass. 
- Sage grouse avoided areas identified through satellite imagery as having highly d?graded vegetative cover.

- There was no clear pattern in terms of preference/avoidance of previously sprayed knapweed control areas by sage grouse.

\section{Recommendations}

It is clear that the two physical habitat characteristics that sage grouse strongly select-low slope angle and elevations in the range of 600 to $800 \mathrm{~m}$ place the birds in areas that are also desirable for troop training on the YTC. Training activities that dramatically reduce sagebrush cover will almost certainly have a lasting negative impact on the grouse population. Thus, mapping sagebrushdominated vegetation on the YTC with the ultimate aim to protect existing quality sage grouse habitat should be a priority effort for sage grouse management on the YTC.

Over the long term, restoration of sagebrush-dominated vegetation is probably the only strategy that holds promise for sage grouse population recovery. Eberhardt and Hofmann (1991) suggested that the YTC sage grouse population in the late 1980s had diminished from what it had been in the early 1980s. They also identified areas that could, but currently do not support sagebrush. Cumulative vegetation degradation maps based on remote sensing data similar to the map shown in Figure $11 \mathrm{~b}$ might be effectively used with a GIS map overlay of the Eberhardt and Hofmann map to identify specific sites for restoration plantings of sagebrush. Usefulness of sagebrush plantings as nesting habitat may also be enhanced if the plantings are located inside the buffer areas known to contain the majority of known nest sites (see Figure 9).

Portions of the extreme northwest corner of the YTC (Training Area 2C) appear to have had a sizable amount of recently degraded vegetation cover (see Figure 11b) that formerly had sagebrush cover [see Figure 16 from the Eberhardt and Hofmann (1991)]. In addition it should be noted in 1991 and 1992 no birds were observed on three minor leks that birds had frequented as recently as 1989 (Eberhardt and Hofmann 1991). Thus, sagebrush restoration in Training Area 2C seems to have potential for expanding the current sage grouse habitat on the YTC. That area was infrequently used in 1991 and 1992 (see Figure 6).

Relatively undisturbed sagebrush-dominated vegetation provides valuable sage grouse habitat. It is unknown, however, the extent of degradation, shor of total loss of sagebrush, that renders preferred habitat unsuitable for use by the birds. 


\section{References}

Amstrup, S. C. 1980. “A Radio-Collar for Game Birds.” J. Wildl. Manage. 44:214-217.

Beck, T. D., R. B. Gill, and C. E. Braun. 1975. "Sex and Age Determination of Sage Grouse from Wing Characteristics." Colorado Department of Game Information Leaflet No. 49, Colorado Department of Game, Fort Collins, Colorado.

Braun, C. E. 1993. "The Status of Sage Grouse: Are they Endangered, Threatened or?" In Abstracts: First Joint Meeting Prairie Grouse Technical Council and Westem States Sage/Coloumbian Sharp-Tailed Grouse Workshop, July 26 - 28, 1993. Fort Collins, Colorado.

Call, M. W., and C. Maser. 1985. Wildlife Habitats in Managed Rangelands-The Great Basin of Southeastern Oregon: Sage Grouse. U.S. Department of Agriculture, Forest Service, General Technical Report PNW-187, Pacific Northwest Forest and Range Experiment Station, Portland, Oregon.

Carr, H. D. 1967. Effects of Sage Brush Spraying on Abundance, Distribution, and Movements of Sage Grouse. M.S. Thesis, Colorado State University, Fort Collins, Colorado.

Connelly, J. W., H. W. Browers, and R. J. Gates. 1988. "Seasonal Movements of Sage Grouse in Southeastern Idaho. J. Wildl. Manage. 52(1):116-122.

Crawford, J. A., and R. S. Lutz. 1985. "Sage Grouse Population Trends in Oregon, 1941-1983." Murrelet 66:69-74.

Dalke, P. D., D. B. Pyrah, D. C. Stanton, J. E. Crawford, and E. Schlatterer. 1960. "Seasonal Movement and Breeding Behavior of Sage Grouse in Idaho." Transactions of the North American Wildlife and Natural Resources Conference 25:396-407.

Downs, J. L., N. A. Cadoret, and W. H. Rickard. 1994. Vegetation Survey of Knapweed on the Yakima Training Center-1992. PNL-9448, Pacific Northwest Laboratory, Richland, Washington.

Eberhardt, L. E., and L. A. Hofmann. 1991. Sage Grouse on the Yakima Training Center: A Summary of Studies Conducted During 1989 and 1990. PNL-7647, Pacific Northwest Laboratory, Richland, Washington.

Emmons, S. R., and C. E. Braun. 1984. "Lek Attendance of Male Grouse." J. Wildl. Manage. 48:1023-1028.

Giesen, K. M., T. J. Schoenberg, and C. E. Braun. 1982. "Methods for Trapping Sage Grouse in Colorado." Wildl. Soc. Bull. 10:224-231.

Hayden-Wing, L. D., D. B. Costain, J. L. Hull, M. R. Jackson, and T. B. Segerstrom. 1986. "Movement Patterns and Habitat Affinities of a Sage Grouse Population in Northeastern Wyoming." In Issues and Technology in the Management of Impacted Western Wildlife, Proceedings of a National Symposium, pp. 207-226, Thome Ecological Institute, Glenwood Springs, Colorado.

Jenni, D. A., and J. E. Hartzler. 1978. "Attendance at a Sage Grouse Lek: Implications for Spring Censuses." J. Wildl. Manage. 42(1):46-52. 
Johnsgard, P. A. 1973. Grouse and Quails of North America. University of Nebraska Press, Lincoln, Nebraska.

Klebenow, D. A. 1969. "Sage Grouse Nesting and Brood Habitat in Idaho." J. Wildl. Manage. 33(3):649-662.

Neu, C. W., C. R. Byers, and J. M. Peek. 1974. "A Technique for analysis of Utilization-Availability Data." J. Wildl. Manage. 38:541-545.

Oakleaf, R. J. 1971. The Relationship of Sage Grousc to Upland Meadows in Nevada. M.S. Thesis, University of Nevada, Reno, Nevada.

Patterson, R. L. 1952. The Sage Grouse in Wyoming. Sage Books, Inc., Denver, Colorado.

Pedersen, W. T. 1981. Sage Grouse Movements and Seasonal Use of Habitats in Eastern Washington. Prog. Rept., Proj. W-70-R-20, Washington Department of Wildlife, Olympia, Washington.

Rogers, G. E. 1964. Sage Grouse Investigation in Colorado. Technical Publication \#16, Colorado Game, Fish and Parks Department, Denver, Colorado.

Schoenberg, T. J. 1982. Sage Grouse Movements and Habitat Selection in North Park, Colorado. M.S. Thesis, Colorado State University, Fort Collins, Colorado.

Stephan, J., P. Beedlow, G. Petrie, L. McWethy, K. Steinmaus, C. Kimball, D. Gibbons, J. Waugh, G. Wukelic, L. Rogers, and R. Hanna. 1990. Vegetation/Landcover Map for the U.S. Army Yakima Firing Center, Washington. PNL-7310, Pacific Northwest Laboratory, Richland, Washington.

U.S. Army Corps of Engineers. 1987. GRASS Users and Programmers Manual for the Geographical Resources Analysis Support System. USA-CERL ADP Report N-87/22, Construction Engineering Research Laboratory, Champaign, Illinois.

Wallestad, R. 1975. Life History and Habitat Requirements of Sage Grouse in Central Montana. Montana Department Fish and Game, Helena, Montana.

Wallestad, R., and P. Schladweiler. 1974. "Breeding Season Movements and Habitat Selection of Male Sage Grouse." J. Wildl. Manage. 38(4)634-637.

Yocom, C. F. 1956. "The Sage Hen in Washington State." Auk. 73:540-550. 
Appendix A

1991 and 1992 Sage Grouse Relocation Data Summary 


\section{Appendix A}

\section{1 and 1992 Sage Grouse Relocation Data Summary}

$\begin{array}{ccc}\text { Bird ID } & \text { Sex } & \text { Lek } \\ 8280 & \text { M } & 5 \\ 8240 & \text { M } & 10 \\ 8460 & \text { M } & 10 \\ 8125 & \text { F } & 10 \\ 8260 & \text { M } & 10 \\ 8360 & \text { F } & 10 \\ 8400 & \text { F } & 10 \\ 8440 & \text { F } & 10 \\ 8185 & \text { F } & 19 \\ 8805 & \text { F } & 19 \\ 9163 & \text { F } & 19 \\ 9207 & \text { F } & 19 \\ 9245 & \text { F } & 19 \\ 8042 & \text { M } & 55 \\ 8122 & \text { M } & 55 \\ 8205 & \text { F } & 55 \\ 8300 & \text { F } & 55 \\ 8381 & \text { M } & 55 \\ 8999 & \text { M } & \text { Beller }\end{array}$

1991

$\begin{array}{cl}\text { \# relocations } & \text { Dates } \\ 48 & 2 / 25-9 / 10 \\ 49 & 3 / 9-10 / 18 \\ 34 & 2 / 25-9 / 10 \\ 54 & 3 / 3-11 / 1 \\ 43 & 4 / 4-10 / 14 \\ 33 & 3 / 19-10 / 14 \\ 58 & 3 / 6-12 / 27 \\ 56 & 3 / 8-10 / 14 \\ 23 & 1 / 25-11 / 1 \\ 56 & 1 / 25-12 / 4 \\ 5 & 6 / 12-7 / 16 \\ 42 & 3 / 14-12 / 27 \\ 20 & 4 / 17-11 / 26 \\ 37 & 2 / 25-7 / 11 \\ 18 & 4 / 2-9 / 5 \\ 16 & 3 / 3-4 / 25 \\ 57 & 2 / 25-8 / 12 \\ 17 & 4 / 2-7 / 19 \\ 11 & 3 / 19-7 / 15 \\ 677 & \text { total }\end{array}$

1992

Bird ID
8045
8063
8244
8364
8587
8723
8884
9100
9220
8105
8145
8224
8264
8270
8284
8325

Sex Lek

F 10

F 10

F $\quad 10$

$\mathrm{F} \quad 10$

F 10

$F \quad 10$

F 10

F 10

$\mathrm{F} \quad 10$

F 19

F 19

F 19

F 19

F 19

F 19

F 19

$\begin{array}{cl}\text { \# relocations } & \text { Dates } \\ 1 & 3 / 19 \\ 13 & 3 / 18-9 / 3 \\ 21 & 3 / 19-11 / 25 \\ 17 & 3 / 27-10 / 26 \\ 2 & 3 / 13-3 / 26 \\ 14 & 3 / 18-11 / 24 \\ 6 & 3 / 27-8 / 16 \\ 15 & 3 / 18-10 / 26 \\ 5 & 1 / 2-3 / 30 \\ 16 & 3 / 17-8 / 18 \\ 21 & 3 / 16-11 / 18 \\ 13 & 3 / 16-5 / 12 \\ 17 & 3 / 22-10 / 26 \\ 18 & 3 / 17-12 / 1 \\ 19 & 3 / 16-11 / 18 \\ 23 & 3 / 17-12 / 1\end{array}$

A. 1 


\begin{tabular}{|c|c|c|c|c|}
\hline 8445 & $F$ & 19 & 19 & $3 / 17-12 / 1$ \\
\hline 8527 & $F$ & 19 & 17 & $3 / 23.11 / 18$ \\
\hline 8606 & $F$ & 19 & 22 & $3 / 19-10 / 26$ \\
\hline 8624 & $F$ & 19 & 13 & $3 / 18 \cdot 5 / 11$ \\
\hline 8767 & $F$ & 19 & 13 & $3 / 17-9 / 8$ \\
\hline 8785 & $F$ & 19 & 7 & $3 / 17-4 / 16$ \\
\hline 8865 & $F$ & 19 & 24 & $3 / 17-11 / 18$ \\
\hline 8925 & $F$ & 19 & 16 & $3 / 17 \cdot 11 / 24$ \\
\hline 8963 & $F$ & 19 & 16 & $3 / 23-11 / 18$ \\
\hline 9085 & $F$ & 19 & 19 & $3 / 16-11 / 19$ \\
\hline 9145 & $F$ & 19 & 13 & $3 / 29-11 / 19$ \\
\hline 9243 & $F$ & 19 & 2 & $7 / 16-8 / 18$ \\
\hline 9305 & $F$ & 19 & 1 & $4 / 10$ \\
\hline 9364 & $F$ & 19 & 17 & $3 / 24-6 / 16$ \\
\hline 8565 & $\mathbf{F}$ & 55 & 12 & $3 / 19-10 / 12$ \\
\hline 8705 & $\mathbf{F}$ & 55 & 7 & $3 / 20-7 / 20$ \\
\hline 8163 & $\mathbf{F}$ & Beller & 22 & $3 / 17-11 / 25$ \\
\hline 8545 & $\mathbf{F}$ & Beller & 3 & $3 / 16-3 / 27$ \\
\hline 8645 & $\mathrm{~F}$ & Beller & 21 & $3 / 16-11 / 24$ \\
\hline 8664 & $F$ & Beller & 9 & $3 / 16-8 / 21$ \\
\hline 8944 & $\mathrm{~F}$ & Beller & 4 & $3 / 16-3 / 31$ \\
\hline 8985 & $\mathrm{~F}$ & Beller & 11 & $3 / 16-11 / 25$ \\
\hline 9023 & $F$ & 5 & 7 & $3 / 18-7 / 1$ \\
\hline 9060 & $\mathbf{F}$ & 5 & 14 & $3 / 19 \cdot 10 / 26$ \\
\hline 9140 & $\mathbf{F}$ & 5 & 6 & $3 / 19-4 / 23$ \\
\hline 9160 & $\mathbf{F}$ & 5 & 16 & $3 / 19-9 / 4$ \\
\hline 9500 & $\mathrm{~F}$ & 5 & 9 & $3 / 27-7 / 8$ \\
\hline 8304 & $\mathrm{~F}$ & Squaw & 26 & $3 / 18-11 / 25$ \\
\hline 8424 & $\mathrm{~F}$ & Squaw & 21 & $3 / 19-11 / 25$ \\
\hline 8464 & $\mathrm{~F}$ & Squaw & 11 & $3 / 29-12 / 3$ \\
\hline 8825 & $F$ & Squaw & $\begin{array}{l}19 \\
638\end{array}$ & $\begin{array}{l}3 / 19-9 / 8 \\
\text { total }\end{array}$ \\
\hline
\end{tabular}


Appendix B

\section{Weekly Maximum Count Data for Male and Female Sage Grouse on Leks in 1991 and 1992}




\section{Appendix B}

\section{Weekly Maximum Count Data for Male and Female Sage Grouse on Leks in 1991 and 1992}

\begin{tabular}{|c|c|c|c|c|c|c|c|c|c|c|c|c|c|c|c|}
\hline \multirow{4}{*}{$\begin{array}{l}\text { Week } \\
\text { Monitored } \\
\text { 2/8-2/11 }\end{array}$} & \multicolumn{4}{|c|}{ Range 19} & \multicolumn{4}{|c|}{ Range 15} & \multicolumn{4}{|c|}{ Range 10} & \multicolumn{3}{|c|}{ Range 5} \\
\hline & & 991 & & 992 & & 91 & & & 19 & & 19 & & & & 1992 \\
\hline & $\mathbf{M}$ & $\mathbf{F}$ & $\mathbf{M}$ & & $\mathbf{M}$ & $\mathbf{F}$ & $\mathbf{M}$ & $\mathbf{F}$ & $\mathbf{M}$ & $\mathbf{F}$ & $\mathbf{M}$ & $\mathbf{F}$ & $\mathbf{M}$ & $\mathbf{F}$ & \\
\hline & 0 & 0 & & & 5 & 0 & & & 6 & 5 & & & 13 & 0 & \\
\hline $2 / 12-2 / 17$ & 0 & 0 & 18 & 1 & 0 & 0 & 0 & 0 & 0 & 0 & 6 & 0 & 0 & 0 & \\
\hline $2 / 18-2 / 24^{\circ}$ & 47 & 23 & 15 & 3 & 1 & 0 & 0 & 0 & 8 & 5 & 5 & 1 & 11 & 3 & 15 \\
\hline $2 / 25-3 / 3$ & 1 & 0 & 36 & 24 & 3 & 2 & 0 & 0 & 7 & 6 & 9 & 5 & 7 & 3 & 0 \\
\hline $3 / 4-3 / 10$ & 35 & 4 & 30 & 38 & 0 & 0 & 0 & 0 & 9 & 8 & 8 & 7 & 0 & 0 & 2 \\
\hline $3 / 17$ & 50 & 9 & 35 & 13 & 1 & 0 & 0 & 0 & 10 & 4 & 7 & 6 & 25 & 0 & 0 \\
\hline $3 / 18-3 / 24$ & 20 & 0 & 17 & 0 & 0 & 0 & 0 & 0 & 10 & 3 & 0 & 0 & 0 & 0 & 11 \\
\hline & 0 & 0 & & & 0 & 0 & & & & 0 & & & 23 & 0 & \\
\hline $4 / 1-4 \pi$ & 48 & 2 & & & 0 & 0 & & & 14 & 2 & & & 0 & 0 & \\
\hline $4 / 8-4 / 14$ & 62 & 5 & & & 4 & 0 & & & 16 & 2 & & & 33 & 2 & \\
\hline $4 / 15-4 / 21$ & 51 & 1 & & & 2 & 0 & & & 13 & 1 & & & 16 & 3 & \\
\hline $4 / 22-4 / 27$ & 53 & 2 & & & 1 & 0 & & & 0 & 0 & & & 0 & 0 & \\
\hline $4 / 28-5 / 4$ & 0 & 0 & & & 0 & 0 & & & 0 & 0 & & & 0 & 0 & \\
\hline
\end{tabular}

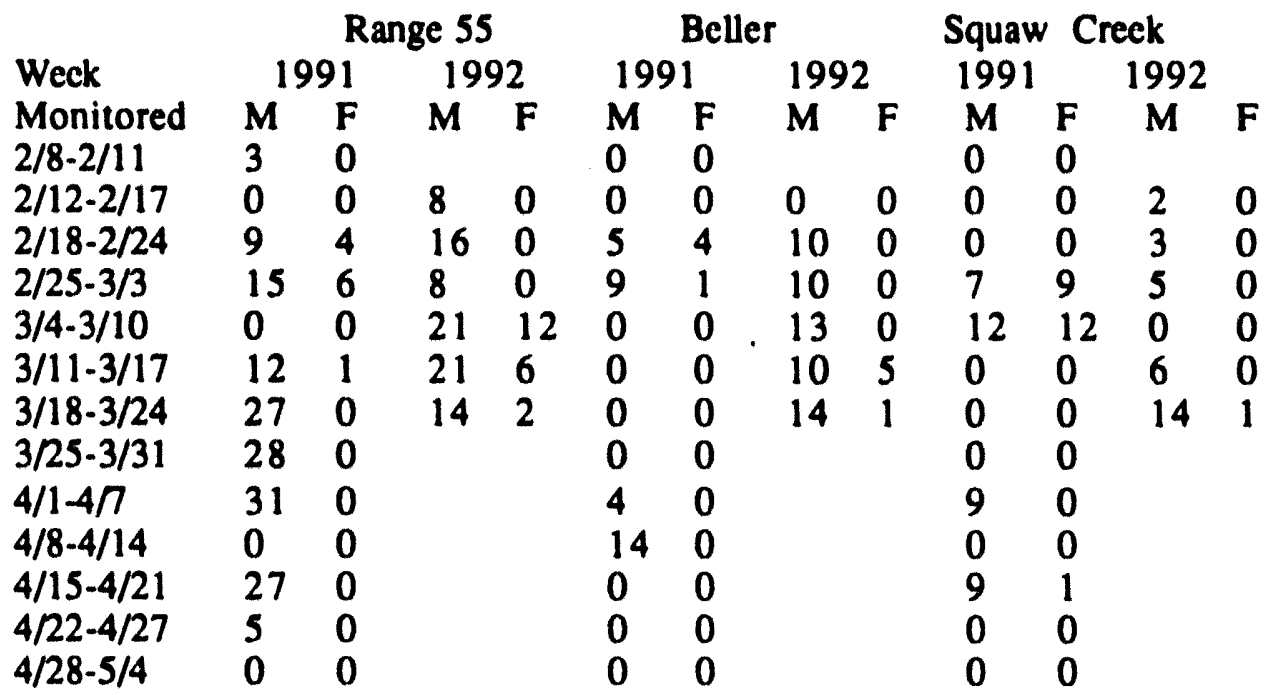

B.1 


\section{Appendix C}

Monthly Average Distances Moved by Male and Female Grouse from Their Lek 


\section{Appendix C}

\section{Monthly Average Distances Moved by Male and Female Grouse from Their Lek}

\begin{tabular}{|c|c|c|c|c|c|c|}
\hline Sex & Month & $\begin{array}{c}\text { Average } \\
\text { Distance }(m)\end{array}$ & $\begin{array}{l}\text { Standard } \\
\text { Deviation }\end{array}$ & $95 \%$ Interval* & $\begin{array}{l}\text { Number } \\
\text { Relocations }\end{array}$ & $\begin{array}{c}\text { Number } \\
\text { Birds }\end{array}$ \\
\hline \multirow[t]{15}{*}{ Female } & January & 1680.83 & 236.58 & 267.71 & 3 & 2 \\
\hline & February & 2018.41 & 917.63 & 519.19 & 12 & 3 \\
\hline & March & 4084.08 & 3378.95 & 834.37 & 63 & 9 \\
\hline & April & 5356.53 & 4560.47 & 1053.39 & 72 & 10 \\
\hline & May & 7370.91 & 6289.18 & 1779.18 & 48 & 10 \\
\hline & Avg Spring & 5181.88 & 4788.90 & 667.04 & 198 & \\
\hline & June & 6735.14 & 5742.61 & 1045.03 & 116 & 10 \\
\hline & July & 7536.76 & 6188.21 & 1849.60 & 43 & 9 \\
\hline & August & 6652.69 & 5001.07 & 2450.48 & 16 & 6 \\
\hline & Avg Summer & 6924.57 & 5772.20 & 855.20 & 175 & \\
\hline & September & 8957.22 & 7477.74 & 4230.85 & 12 & 6 \\
\hline & October & 7168.00 & 5687.26 & 2979.11 & 14 & 8 \\
\hline & November & 3483.84 & 2695.24 & 1465.12 & 13 & 6 \\
\hline & Docember & 1823.20 & 909.69 & 1260.74 & 2 & 2 \\
\hline & Avg Fall & 6262.80 & 5835.17 & 1764.72 & 42 & \\
\hline \multirow[t]{15}{*}{ Male } & January & & & & 0 & \\
\hline & February & 2531.27 & 2892.76 & 2004.54 & 8 & 3 \\
\hline & March & 2184.38 & 2381.18 & 915.28 & 26 & 5 \\
\hline & April & 1910.70 & 3586.69 & 885.67 & 63 & 8 \\
\hline & May & 10516.23 & 4771.30 & 1537.39 & 37 & 7 \\
\hline & Avg Spring & 4377.01 & 5308.14 & 898.75 & 134 & \\
\hline & June & 12567.88 & 4361.41 & 1021.71 & 70 & 8 \\
\hline & July & 12877.80 & 4261.39 & 1578.41 & 28 & 8 \\
\hline & August & 12409.27 & 3854.27 & 2670.82 & 8 & 4 \\
\hline & Avg Summer & 12637.78 & 4264.11 & 811.75 & 106 & \\
\hline & September & 7362.26 & 2835.79 & 1604.47 & 12 & 5 \\
\hline & October & 6662.52 & 4121.66 & 4039.15 & 4 & 2 \\
\hline & November & & & & 0 & \\
\hline & December & & & & 0 & \\
\hline & Avg Fall & 7187.32 & 3064.77 & 1501.71 & 16 & \\
\hline
\end{tabular}

* 95\% Confidence Interval = Average Distance $\pm 95 \%$ Interval

C. 1 


\section{Distribution}

No. of

Copies

Ofisite

12 DOE Office of Scientific and Technical Information

30 Commander

Yakima Training Center

Attn: AFZH-Y-ENV

(Steven M. Kruger)

Yakima, WA 98901

5 R. W. Hanna

Deparment of the Army

HQ-I Corps

Attn: AFZH-DEQ

Fort Lewis, WA 98433-5000

C. Sveum

Oregon State University

Nash Hall, 104

Corvallis, OR 97331

\section{Onsite}

DOE Richland Operations Office

R. D. Hildebrand
No. of

Copies

21 Pacific Northwest Laboratory

L. L. Cadwell (10)

J. L. Downs

R. Mazaika

L. E. Rogers

M. A. Simmons

B. L. Tiller

Publication Coordination

Technical Report Files (5)

Routing

R. M. Ecker

M. J. Graham

P. M. Irving

C. W. Sloane

P. C. Hays/G. P. O'Connor (last)

Distr.1 

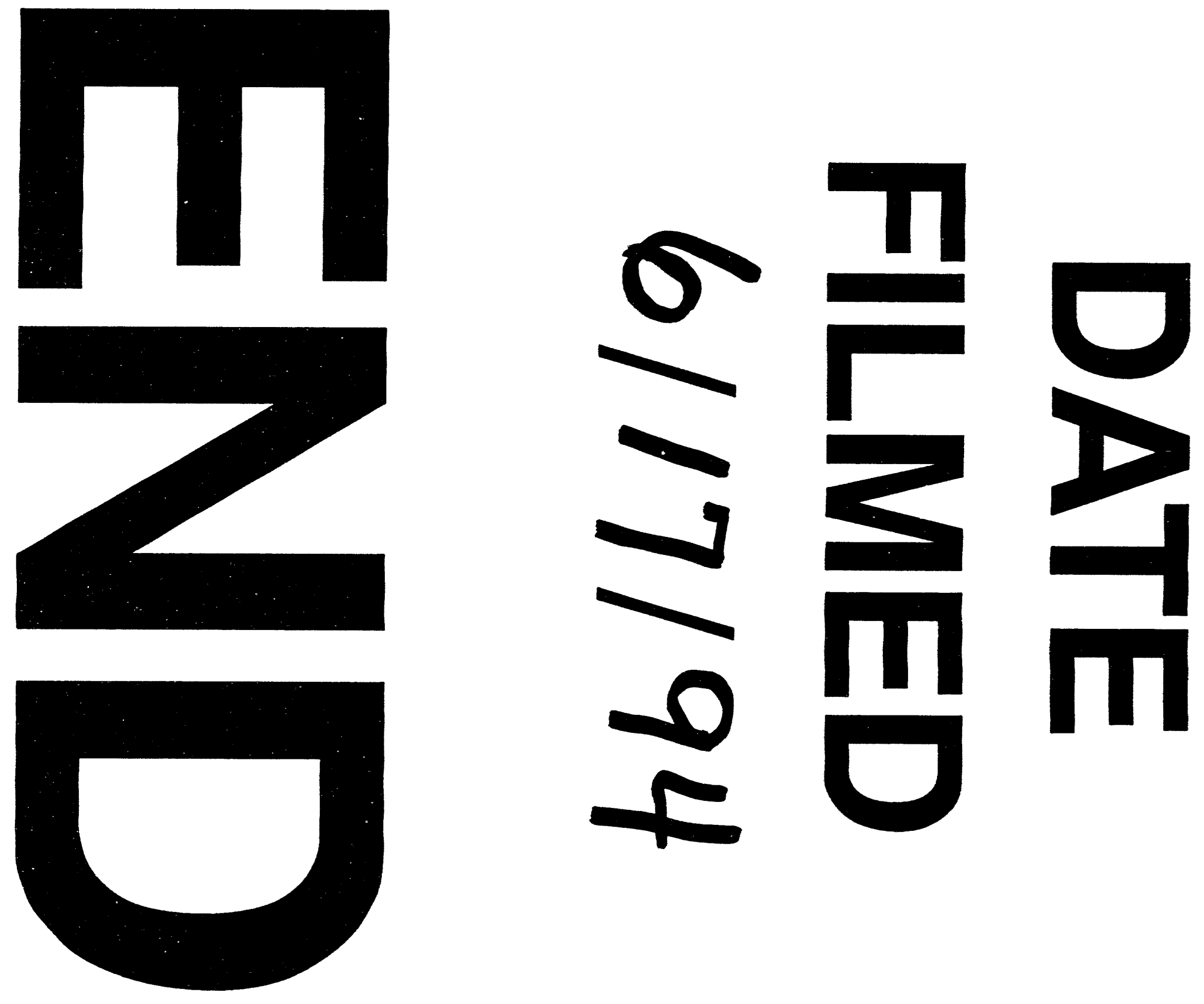